DOI: https://doi.org/10.46630/phm.12.2020.49

Микоња В. Кнежевић*

Универзитет у Приштини

са привременим седиштем у Косовској Митровици

Филозофски факултет

Студијски програм за филозофију
Оригинални научни рад

УДК 091=163.1"13/14“"

Примљен: 31. 3. 2020.

\title{
ПАЛАМИНО „ИЗЛОЖЕЮЕ НАОПАКОГ МНОШТВА ВАРЛААМОВИХ И АКИНДИНОВИХ ЗЛОЧЕСТИ“. СРПСКОСЛОВЕНСКИ ПРЕПИС ИЗ ЗБОРНИКА 41 МАНАСТИРА СВЕТЕ ТРОЈИЦЕ КОД ПЉЕВАљА
}

Спис под називом Изложење наопаког мноштва Варлаамових и Акиндинових злочести састављен је око 1344. године. Настао у јеку расправе коју је Григорије Палама водио са својим бившим учеником, Григоријем Акиндином, он доноси попис ,јереси“ у које су, по Паламином мишљењу, упали његови опоненти. Заједно са неким другим Паламиним трактатима и овај спис је преведен на српскословенски језик, по свој прилици у посљедњем кварталу 14. вијека.

У тексту који слиједи доносим српскословенски превод Изложења, заједно са грчким изворником и преводом на савремени српски језик. За основни текст узет је пети, до сада непознати препис, који сам пронашао у Зборнику 41 рукописне библиотеке Манастира Свете Тројице код Пљеваља. Поред описа Зборника, у уводним напоменама дати су и основни подаци о спису, као и кратак осврт на његову богословску садржину.

Кључне ријечи: Зборник 41, Григорије Палама, српскословенски превод, божанско суштаство, божанске енергије

Зборник $41^{1}$ рукописне библиотеке Манастира Свете Тројице код Пљеваља до сада није био предмет научног истраживања, изузму ли се узгредни осврти на његов обим, полемичку структуру и хронологију

\footnotetext{
* mikonjaknezevic@gmail.com

${ }^{1}$ Изражавам захвалност проф. др Томиславу Јовановићу и др Милеси Стефановић Бановић, који су прокоментарисали радну верзију овог текста; др Владану Тријићу и мр Љиљани Пузовић из Археографског одељења Народне библиотеке Србије, који су ми уступили два преписа Изложень; те братствима манастира Хиландара и манастира Свете Тројице код Пљеваља, који су ме опскрбили снимцима преписа из својих рукописних библиотека.
} 
(LAZIĆ 1999: 178). Настао крајем 14. или у првој деценији 15. вијека (MOŠIN 1958: 253; STANKOVIĆ 2003: 15), протеже се на укупно 362

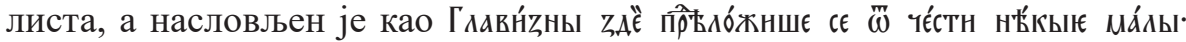

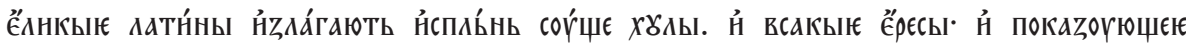

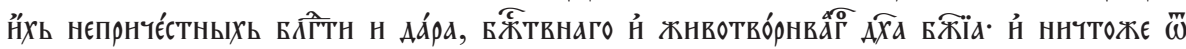

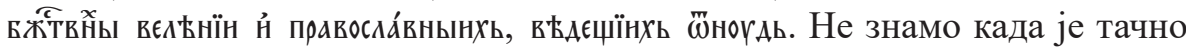
донесен у манастирску библиотеку, која је у више наврата обогаћивана књигама из других манастира (PETKOVIĆ 2008: 105-106), али из које су књиге исто тако изношене (RADOJIČIĆ 1949: 220-221; DURKOVIĆJAKŠIĆ 1957: 228). Из најранијих пописа манастирске рукописне збирке (KOSANOVIĆ 1871: 165-172) није јасно да ли се, у тренутку док су они настајали, Зборник 41 већ налазио у манастиру (VUKIĆEVIĆ 1901)², али из једног инвентара, сачињеног новембра 1894. године, сазнајемо да је зборник тада био у манастирској књижници (DURKOVIĆ-JAKŠIĆ 1957: 232). Како год да било, ова се важна колекција по својој структури понајприје може убројити у зборнике „непостојаног састава“,3 будући да њени текстови, осим различитих питања која су обиљежила спор православних са „Латинима“, обрађују и неке егзегетске и теме из подвижничког живота. Структура Зборника 41 карактеристична је за антилатинске зборнике који су крајем 14. и током 15. вијека били посебно популарни у српским земљама (ŽUNJIĆ 2013: 566). Његов највећи дио запрема расправа о исхођењу Светог Духа (1r-220r), у оквиру које су, осим опширне

\footnotetext{
${ }^{2}$ Хаџи Сава Косановић, потоњи митрополит дабробосански, је у манастиру био 1870. године, гдје је провео „неколико дана“, прегледавши цркву „и све србуље ту налазеће се писане“ (1871: 163). Његов попис, рађен по принципу „како му је која на руку [до] долазила“, обухвата 93 књиге, а под бројем 51 наведен је извјесни „Зборник“ - но без било каквог описа тог рукописа. Мил. М. Вукићевић је у манастиру био 1900. године, гдје је провео 7-8 дана. Он наводи да се „у манастирској књижници, која је доста добро уређена, налази повећи број старих Србуља“ те да их има „до стотине“ (1901: 289). Међутим, у свом прилогу Вукићевић је описао само њих 63 (укључујући и неке штампане књиге), будући да се „као историчар више занимао за записе него за саму садржину рукописа“" (RADOJIČIĆ 1949: 221). На његовом попису Зборника 41 такође нема, иако та књига садржи један запис који би Вукићевићу, као историчару, засигурно привукао пажњу. Коначно, Ђорђе Радојичић (1949: 220) је у манастиру Свете Тројице 1949. године провео 20 дана, прегледавши „113 рукописа“, али се ни он не осврће на колекцију која нас овдје занима. (Занимљиво, Радојичић помиње да се у том тренутку у манастирској библиотеци не налази Хришћанска йойографија Козме Индикоплова са Шесйодневом Јована Егзарха, књиге које су данас (опет) дио манастирске библиотеке) Коначно, Мошин (1958: 253) пописује Зборник 41, али ни код њега не можемо наћи информацију када је та књига постала дио манастирске библиотеке. За разрјешење тог питања од помоћи би могло бити дешифровање идентитета извјесног „ђакона Јанићија“, аутора записа из 1706. године, који се налази на крају Зборника.
}

${ }^{3}$ Средњовјековни зборници могу се класификовати на зборнике а) постојаног, б) релативно постојаног, и в) непостојаног састава (IVANOVA 1985: 173-182; LAZIĆ 1999: $168-169,178)$. 
антологије светописамских перикопа и отачких свједочанстава о том питању, заступљени и краћи изводи из Калиста (34r-40v), шири преноси из Нила Кавасиле, насљедника Григорија Паламе на катедри у Солуну, као и други ексцерпти полемичког карактера. Напоредо са наведеним одјељцима из списа̂ источних отаца (Атанасија Александријског, Василија Великог, Григорија Богослова, Григорија Ниског, Јована Златоустог, Максима Исповједника, Јована Дамаскина и других), ту су дате и опсежне парафразе и изводи из дјела Томе Аквинског (151r-204r), са чијим се теолошким постулатима нашироко полемише. Но, осим „битијног“ исхођења

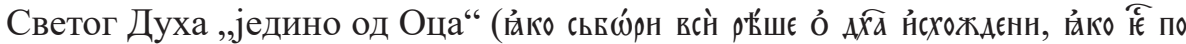
вытїю $\tilde{\omega}$ ӧц्व є́днного), затим, за православне важног разликовања ипостаси и енергије, односно личности и благодатног дејства Светог Духа (ฉ̉ко н̈но

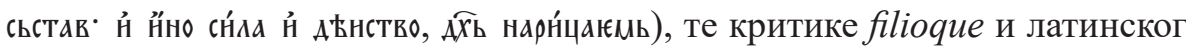
увођења „дијархије“ (двоюндче́ї̈) у Богу, у зборнику се разматрају и друга кључна питања из спора Истока и Запада, а којима су поједини од трактата изравно и у цјелости посвећени. Таква је расправа Варлаама

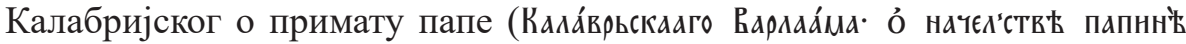
[220v-236v]), ${ }^{4}$ као и низ списа посвећених употреби бесквасног хљеба, у које спадају: трактат Никите Пафлагона о Тајној вечери (Ннкїты фнло́софа

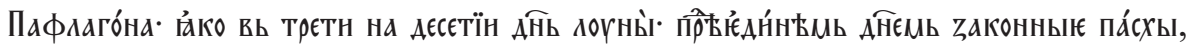

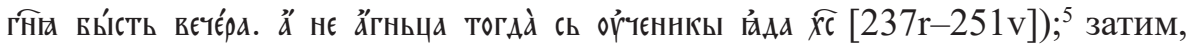

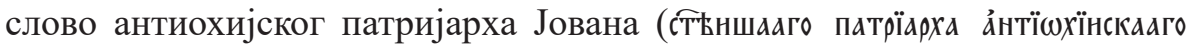

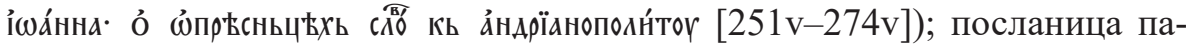

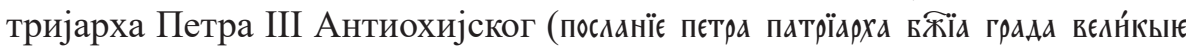

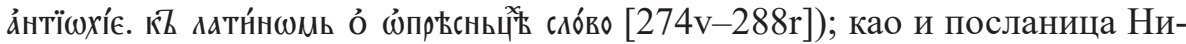
ките Ститата о бесквасном хљебу и посту у суботу (Ннкїты прєzви́тєра й

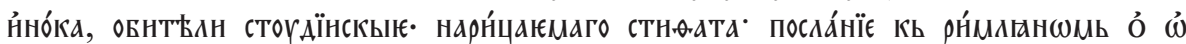

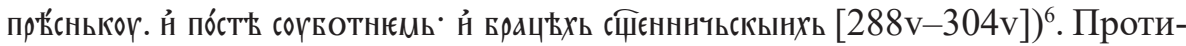
влатинска дионица зборника наставља се пописом „латинских грешака“

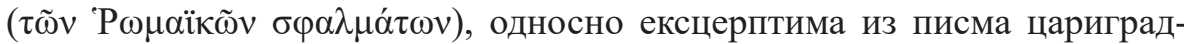

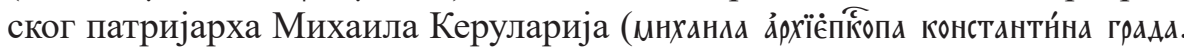

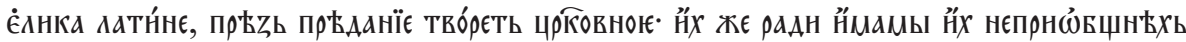
[304v-307r]), ${ }^{7}$ те посланицом коју је истом Михаилу упутио Петар III

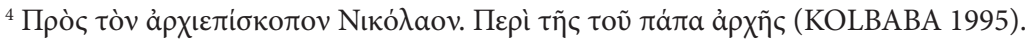

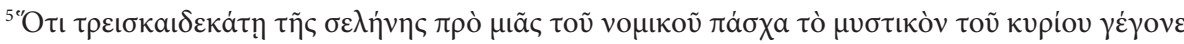

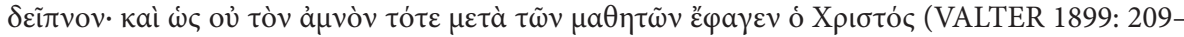
222). Овај текст је задуго приписиван Јовану Филопону (в. PASHALIDES 1999: 223-228).

${ }^{6}$ У шизми двију Цркава Петар III Антиохијски имао је неку врсту посредничке улоге (в. PUZOVIĆ, NIKOLIĆ 2014).

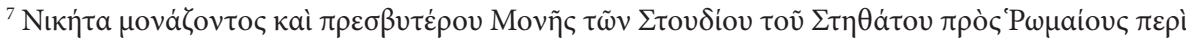

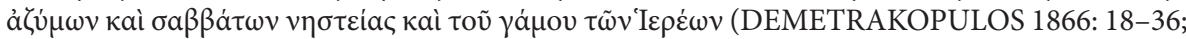
ANTON 1924-1930: 322-342).
} 
Антиохијски (пе́тра патрїа́рха вєли́кыє а̉ніїохнєе посла́нїє о’ сн́хь н̉ о̉ Н̈ныхь пн санїн, к мнхаи́лог констан'тїна града патрїа́рхог [307r-319r]). ${ }^{8}$ Полемички дио зборника окончава се исјечком о Светом Духу Фотија Цариградског (къ

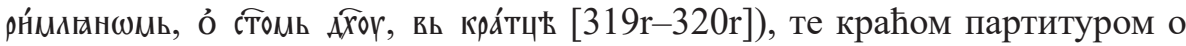
бесквасном хљебу (о́ б̆пьсньццъхь [320r-321v]). ${ }^{9}$ У посљедњем пак дијелу колекције, поред слова о духовном закону Марка Подвижника (а́ввь̀

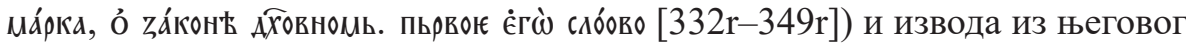
списа о онима који мисле да се оправдају дјелима (о́ грьдєџїнх сє правды [351v-355v]), ${ }^{10}$ те фрагмента из Тумачена Пјесме над пјесмама

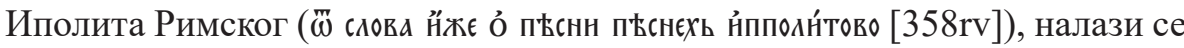
и (до скоро непознати) препис два краћа списа Григорија Паламе: то су Посланица Ани Палеологини (328v-331r) ${ }^{11}$ и Изложење наопаког мноштва Варлаамових и Акиндинових злочести (322r-328v). Како је Паламина обрада питања исхођења Светог Духа већ била предмет пажње српских средњовјековних преводилаца (KAKRIDIS, TASEVA 2014), пренос ова два трактата - заједно са преводом његових $O$ божанском јединству $и$ разликовању и Исповиједања вјере (JEVTIĆ 2013: 509-523) - донио је српској читалачкој публици кратак преглед литерарне продукције потоњег солунског архиепископа из „друге фазе“ исихастичког спора. ${ }^{12} \mathrm{C}$ друге пак стране, Паламина анализа питања filioque, дата у Anoдиктичким словима о исхођењу Светог Духа и у Противнатписима, ${ }^{13}$ сада је употпуњена темељним увидима на исту тему из пера других аутора - у

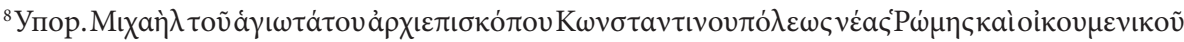

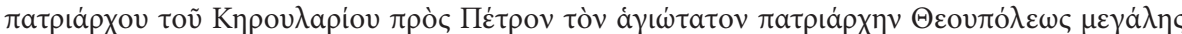
Avvioxeíac, Patrologia Graeca 120, 781B-796A: 789-794. - Српскословенски превод рађен је по предлошку посланице анонимног аутора, која је заснована на Керуларијевом тексту.

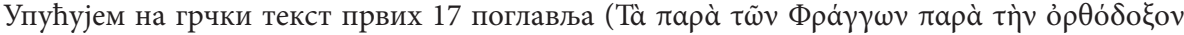

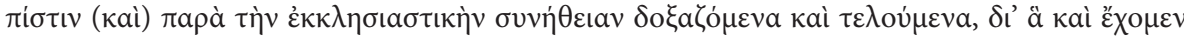

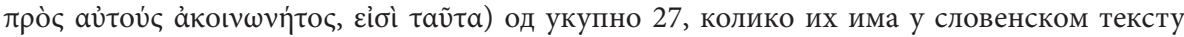
(PAVLOV 1878: 151-157: 151-153/4; в. DARUZE 1963).

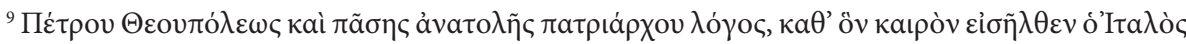

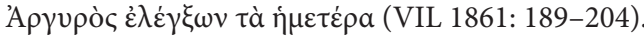

${ }^{10}$ Присуство текстова о употреби бесквасног хљеба у Зборнику 41 је сразмјерно велико, али оно постаје разумљивије узме ли се у обзир да „за већину византијских црквених првака 11. и 12. вијека начелна тачка неслагања са Латинима није била примат папе или чак filioque, већ прије употреба бесквасног хљеба у евхаристији“ (ERIKSON 1970: 156).

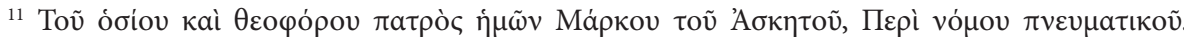

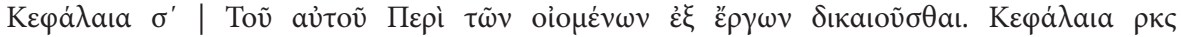
(PHILOKALIA 1782: 91-100; 100-113).

12 Упућујем на скорашње издање овог списа, пропраћено обимном студијом и преводом на савремени српски (KNEŽEVIĆ, STOJANOVIĆ 2019: 197-231)

${ }^{13}$ Григорије Палама је имао широку рецепцију у средњовјековној Србији (в. RADUNOVIĆ 1998; RANKOVIĆ 2013; и најподробније SKARPA 2012).
} 
првом реду, Нила Кавасиле. Сва је прилика да је превођење Паламиних и Кавасилиних антилатинских списа било дио заједничког преводилачког пројекта (SKARPA 2014: 257-258), о чему свједочи и чињеница што се њихови текстови и имена често јављају заједно (ино́жа єжє н̈нынхь

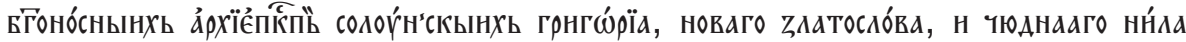
[2r]). Како Нил Кавасила у свом дјелу полемише са теолошким постулатима Томе Аквинског, назначајнијег мислиоца западне схоластике, српска се култура овим путем могла упознати са кључним достигнућима теолошког - и философског - умовања на оба пола хришћанске икумене. ${ }^{14}$ Из тог, али и из многих других разлога, Зборник 41 и њему слични антилатински зборници код Срба ${ }^{15}$ заслужују подробно истраживање, које би имало обухватити њихов детаљан опис, филолошку анализу, испитивање квалитета превода, те дешифровање ауторства и предложака свих текстова који су заступљени у њима.

Синтетички спис под називом Изложење наопаког мноштва Варлаамових и Акиндинових злочести настао је око 1344. године (SINKEVIČ 2002: 142). ${ }^{16}$ У јеку расправе са Григоријем Акиндином, а по свему судећи након састављања првог од својих седам Антиритика (DUNAEV 2009: 16), Палама је у језгровитом облику пописао ,јереси“ у које су упали његови опоненти. Полемички контекст, Паламин психолошки склоп, као и тренд беспоштедне дифамације противника, који је био уобичајен унутар византијске интелектуалне арене, допринијели су да тај попис буде прилично дуг: у укупно четрдесет (од првобитно побројаних „преко педесет“) ,злочести“ упали су, ако је вјеровати Палами, они који су се успротивили његовом виђењу хришћанске вјере (HRESTU 1970: 49-71). У те ,злочести“ убрајају се а),двобоштво“ $(\delta \imath \theta \varepsilon i \alpha v)$, како су најприје Варлаам и Акиндин означили Паламино разликовање суштаства и енергија у Богу; б) различити видови reductio ad absurdum, у које се неминовно упада уколико се не прихвати то разликовање или пак уколико се прихвати створени карактер божанских енергија; в) (алегоријско) поимање енергије као пролазног, акциденталног својства божанског суштаства, или пак њено схватање као самобитног ентитета; г) схватање по којем се

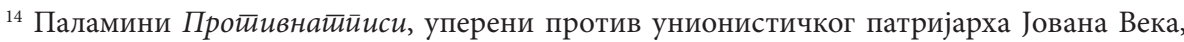
заступљени су у више српских (и руских) зборника (в. SKARPA 2012: 92, 94, 97, 114, 117, $118,122,164)$.

${ }^{15}$ Ово утолико прије што је српска средњовјековна култура изгледа била упућенија у дјело Нила Кавасиле него што је то данас. Ова водећа личност ромејске интелектуалне сцене 14. вијека, у чијем је дјелу дошло до својеврсног сусрета Истока и Запада, једва да је била предмет научне пажње код нас (в. JEVTIĆ 1994).

${ }^{16}$ У њих свакако ваља убројити Рс 474 из Хиландара или пак чувени 3борник Владислава Грамайика (XАЗУ III а 47), у којима се једнако јавља превод антилатинских списа Нила Кавасиле (ŽUNJIĆ 2013: 566-567). Многи текстови садржани у 3борнику 41 присутни су већ у ХИЛ 474, који је настао у посљедњем кварталу 14. вијека.
} 
учествовање у Богу одвија преко божанског суштаства, а не преко благодатног дара, односно енергије Светог Духа; д) поистовјећивање божанске енергије са ипостасима Сина и Светог Духа, и тако даље. Сам спис има форму својеврсног ,исповиједања вјере“, о чему, осим његовог сажетог карактера, свједочи и чињеница што свака од његових тачака започиње карактеристичним

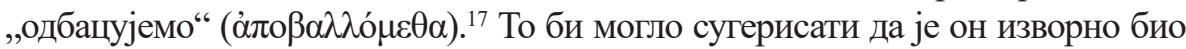
намијењен некоме из редова црквених или свјетовних власти, које је Палама - претпостављамо - хтио убиједити у правовјерност свог, а хетеродоксност Акиндиновог (и Варлаамовог) учења. Изложен у 40 тачака, спис се не одликује оригиналношћу, а логичка страна и извођење аргументације, поглавито усљед жанра за који се аутор опредијелио, у њему скоро сасвим изостају. ${ }^{18}$

Паламино Изложење први пут је објављено у чувеном тому Доситеја Јерусалимског 1698. године (TOMOS AGAPES 1698: 13-17). На српскословенски језик преведено је најкасније у посљедњем кварталу 14. вијека, а тај превод сачуван је у пет преписа. Неки од њих су старији од најстаријег грчког преписа, који је узет за основу критичког издања Изложења и који потиче из 15. вијека (HRESTU 1966: 564, 579-586). То је случај са хиландарским текстом $(474,338 \mathrm{r}-340 \mathrm{v}=$ ХИЛ), који је настао „,у последњој четвртини XIV века“ (1380-1390); затим, са преписом из Универзитетске библиотеке (28, 319r-321v = УБ), који је настао „крајем XIV века“, највјероватније 1395-1400 (CERNIĆ 1981: 353), а вјероватно и са рукописом из Манастира Свете Тројице $(41,322 \mathrm{r}-328 \mathrm{v}=\mathrm{MCT})$, који је настао 1400-1410. Рукопис из Народне библиотеке Србије $(43,415 \mathrm{r}-415 \mathrm{v}=$ НБС), у којем је сачувано тек пет параграфа Изложења (36-41), потиче из 1540, док је онај из Југославенске (сада Хрватске) академије знаности и умјетности (III а 47, 704r-706r = ХАЗУ) настао 1469. године (DANIČIĆ 1869; MOŠIN 1955: I, 61, 66).

У наставку дајем српскословенски превод паралелно са грчким текстом и преводом на савремени српски језик. Српскословенски превод дат је без разрјешавања скраћеница, а за основни текст је узет - до сада непознати - препис из Зборника 41 Манастира Свете Тројице код Пљеваља. У напоменама су дата varia lectiones из осталих преписа, и то редосљедом диктованим хронолошким критеријумом: ХИЛ, УБ, ХАЗУ, НБС. Као што је то случај и са грчким

\footnotetext{
${ }^{17}$ Погрешно се руководећи једним мјестом из Паламине Посланице Гавру, у којој „бранитељ исихаста“ каже како је у једном од својих списа показао „да Акиндин запада у више од педесет лукавих јереси, тиме што не прави никакву разлику између божанског суштаства и енергија“ (HRESTU 1966: 359.19-24), приређивач Изложења је у првом (но не и у потоњем) издању тог текста закључио да је спис о којем је ријеч настао крајем 1342. године (будући да је Посланица Гавру написана децембра исте године). Међутим, како се Паламина референца заираво односи

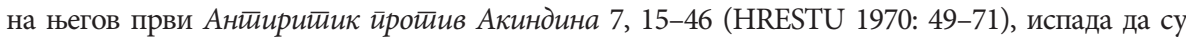
Изложењ $а$ написана нешто касније, по свој прилици крајем 1343. или почетком 1344. године, као својеврсни „кредални“ резиме Паламине полемике са Акиндином.

${ }^{18}$ Није, отуда, случајно што се Паламино Изложење у рукописној традицији често јавља заједно са његовим Исииовиједанем вјере.
} 
сачуваним рукописима, тих „разночтенија“ је у српскословенским преписима мало, а одступања српскословенског превода од грчког текста скоро да и нема. За разлику од неких других његових списа, овај Паламин текст очигледно није ретуширан. Треба напоменути и да у критичком издању Изложење има 40 глава, док је у рукописној традицији њих 41, будући да је у свим сачуваним рукописима први параграф из критичког издања подијељен на двије главе.

\begin{tabular}{|c|c|}
\hline 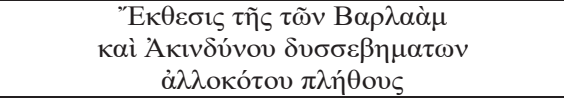 & 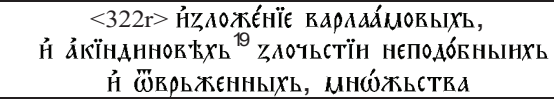 \\
\hline 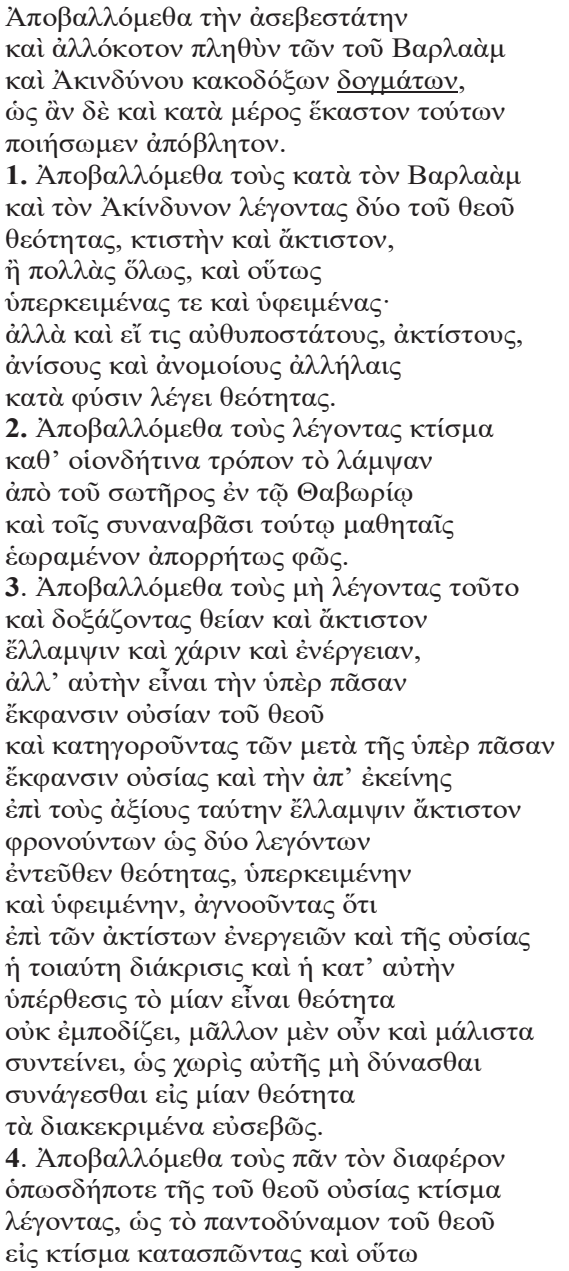 & 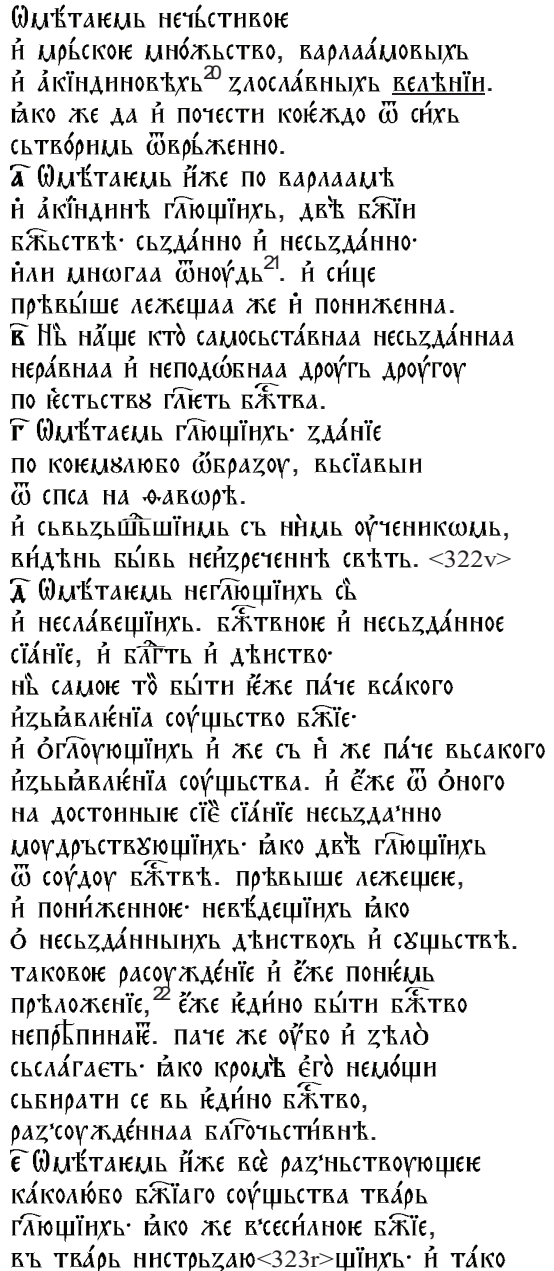 \\
\hline
\end{tabular}

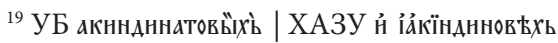

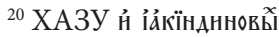

${ }^{21}$ УБ многа Ф̈ногАог

${ }^{22}$ ХАЗУ म̉
} 


\begin{tabular}{|c|c|}
\hline 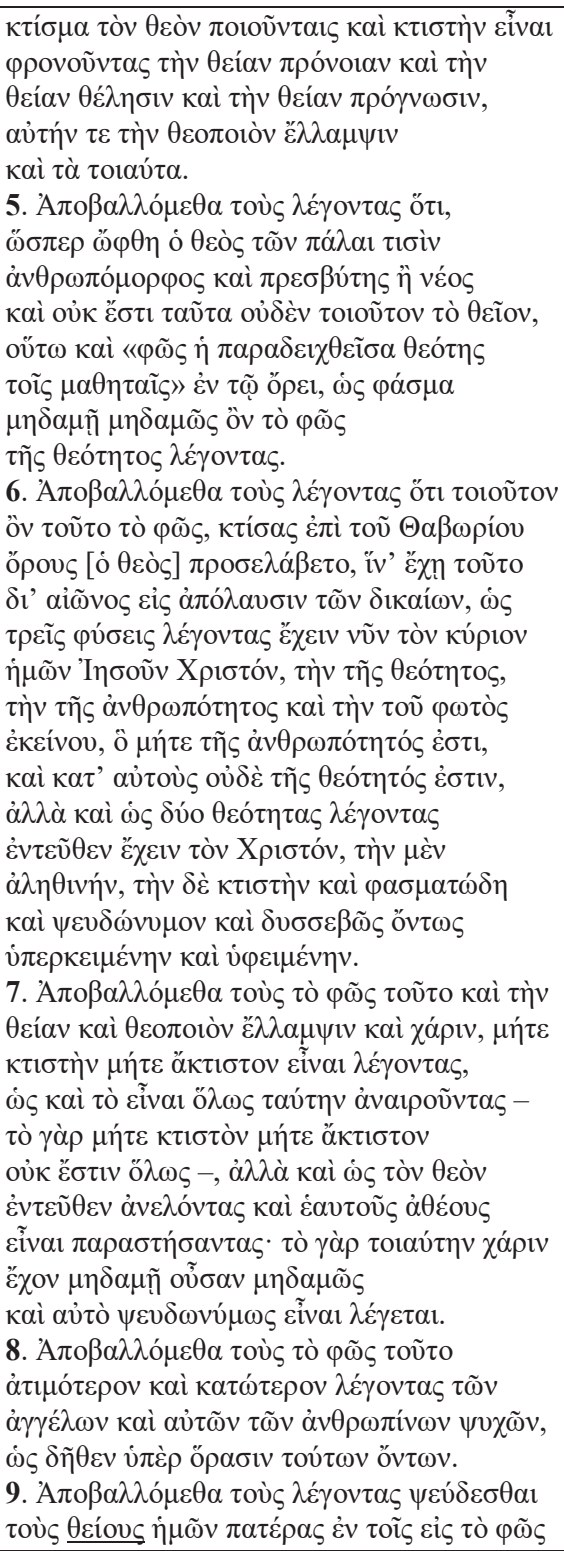 & 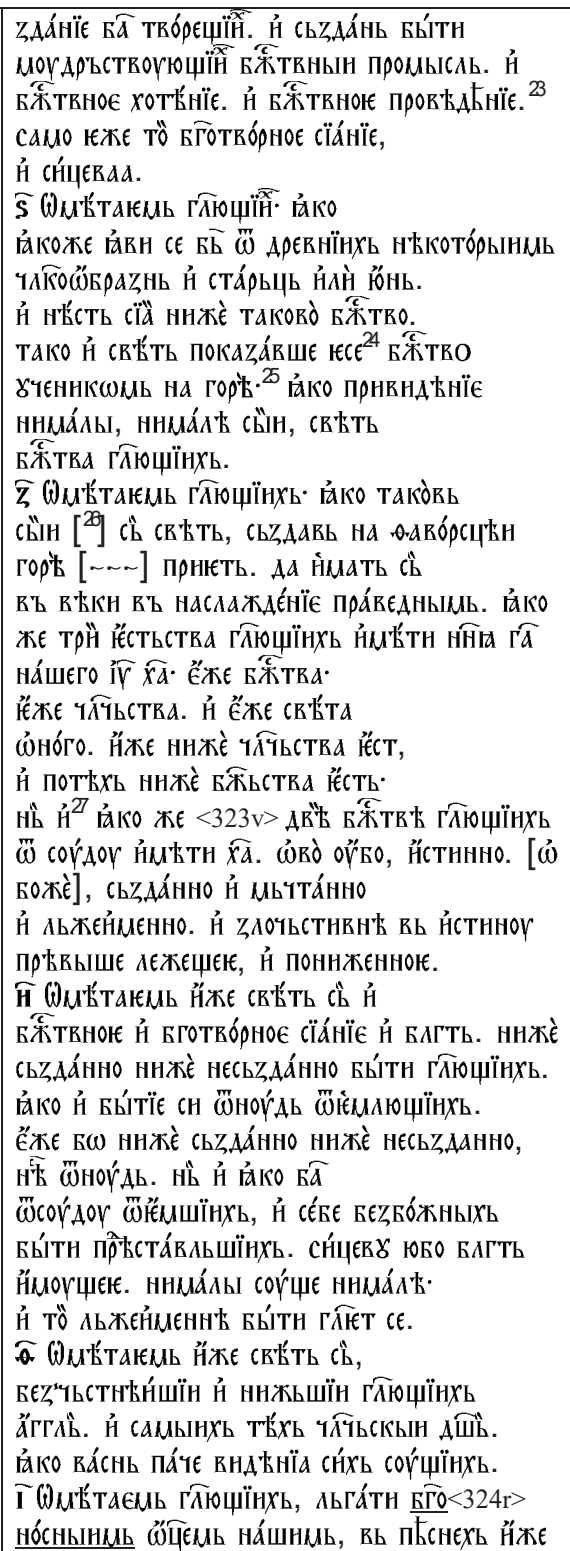 \\
\hline
\end{tabular}

\footnotetext{
${ }^{23}$ ХАЗУ проповћАа́нїє

${ }^{24}$ ХИЛ сє | УБ sine єє $\mid$ ХАЗУ $є$

${ }^{25}$ ХИЛ на го́

${ }^{26}$ ХАЗУ मै

${ }^{27} \mathrm{XA} 3 \mathrm{Y}$ sine $\mathrm{H}$
} 


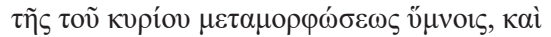

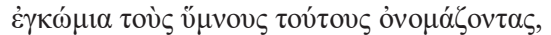

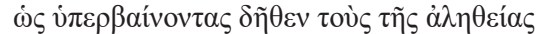

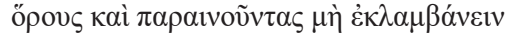

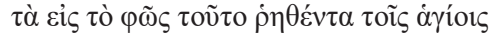

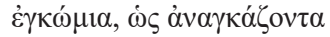

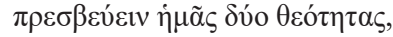

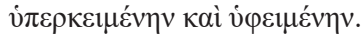

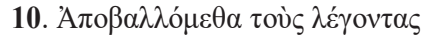

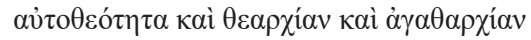

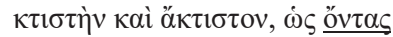

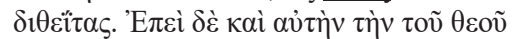

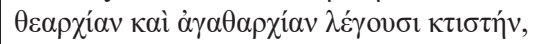

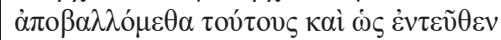

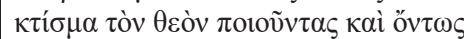

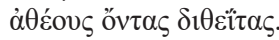

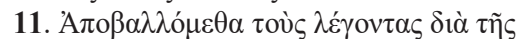

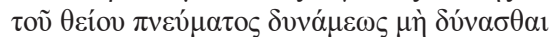

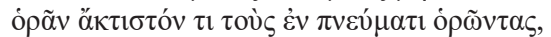

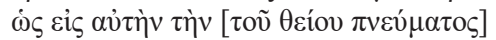

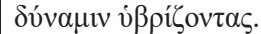

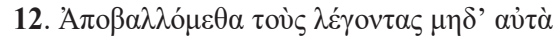

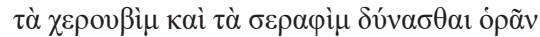

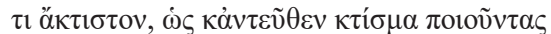

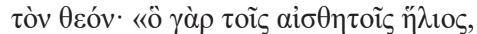

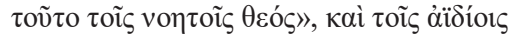

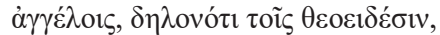

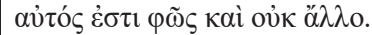

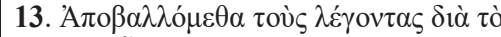

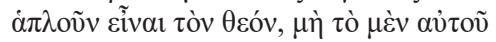

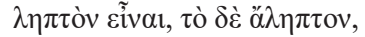

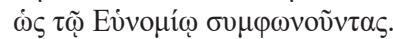

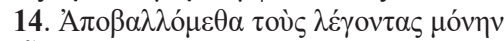

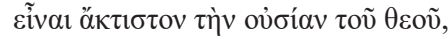

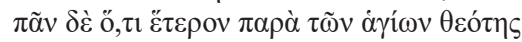

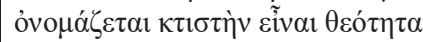

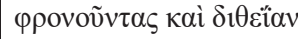

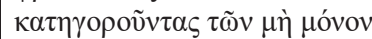

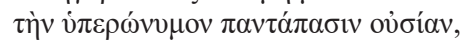

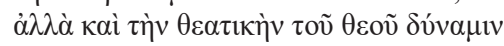

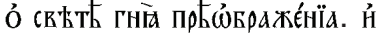

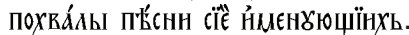

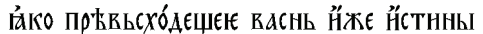

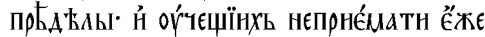

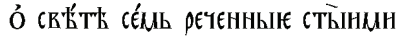

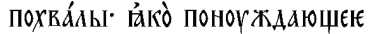

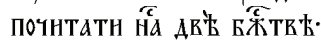

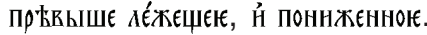

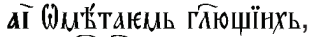

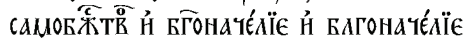

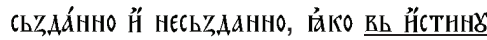

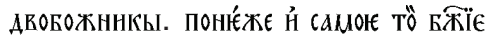
БГัГнначе́

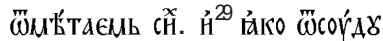

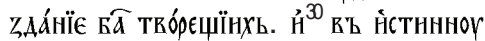
БеzБо́жныє сои́ще АвоБб́жннгкЫ.

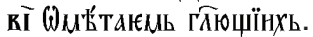

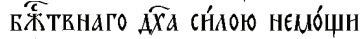

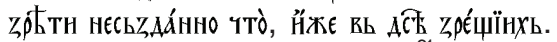

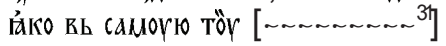
СНАОГ АОСАЖААЮШїНХЬ. $<324 \mathrm{v}>$ Гі̃ GMt́́

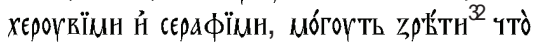

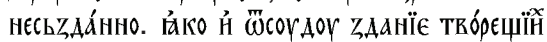

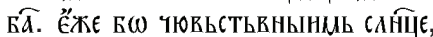

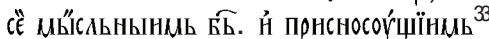

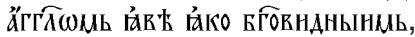

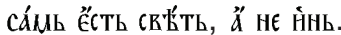

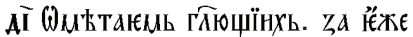

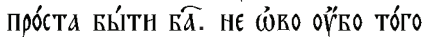

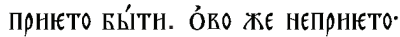

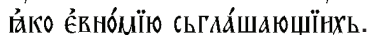

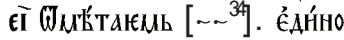

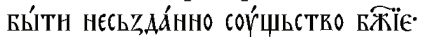

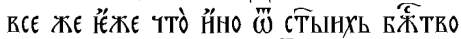

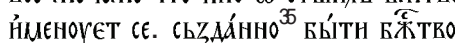

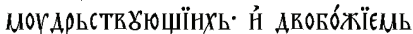

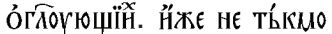

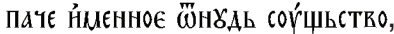

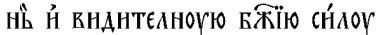

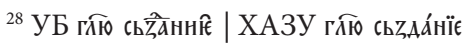

${ }^{29} \mathrm{XA} 3 \mathrm{Y}$ sine $\mathrm{h}$

${ }^{30} \mathrm{XA} 3 \mathrm{Y}$ sine $\mathrm{H}$

${ }^{31}$ ХИЛ | УБ | ХАЗУ

${ }^{32}$ ХИЛ врь

${ }_{33}^{33}$ УБ потносои́щнйщй | ХАЗУ порносои́щнымь

${ }^{34}$ ХИЛ | УБ | ХАЗУ гАюющїнхь

${ }^{35}$ ХИЛ сьзанно
} 


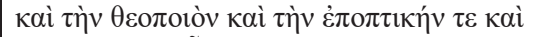

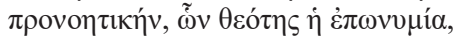

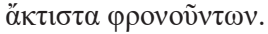

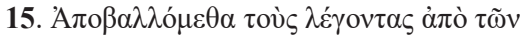

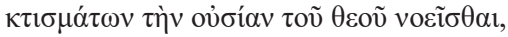

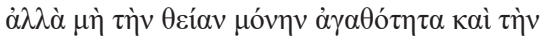

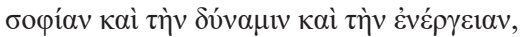
$\kappa \alpha i ̀ \tau \alpha \tilde{v} \tau \alpha \dot{\alpha} \mu \nu \delta \rho \tilde{\omega} \zeta, \dot{\omega} \zeta$

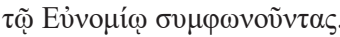

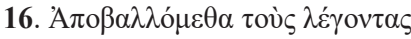

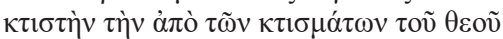

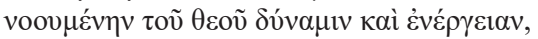

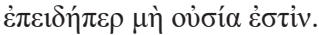

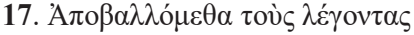

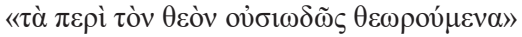

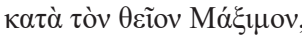

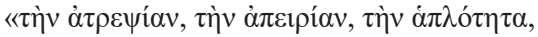

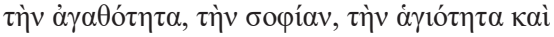

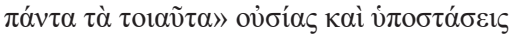

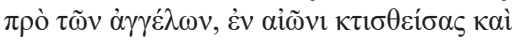

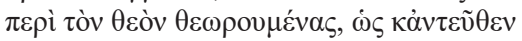

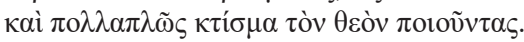

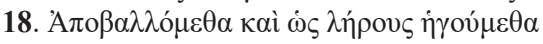

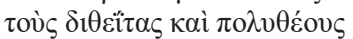

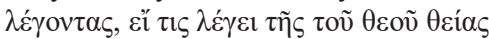

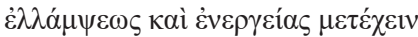

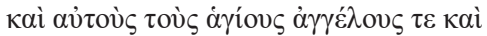

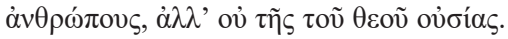

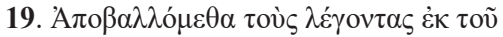

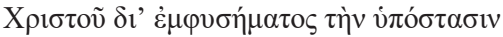

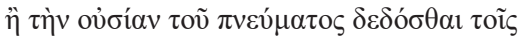

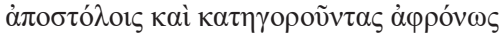

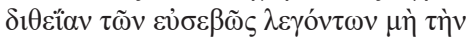

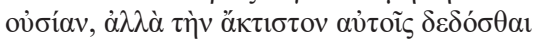

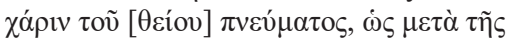

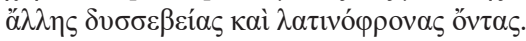

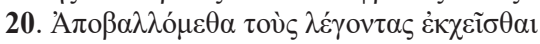

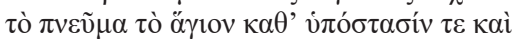

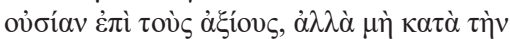

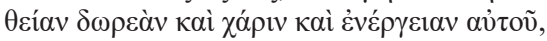

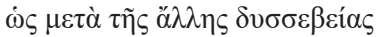

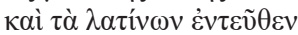



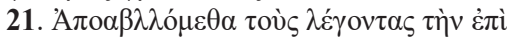

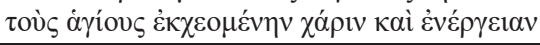

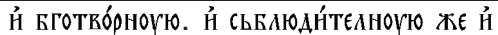

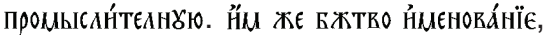
HECZZА́́нHа MоүАрьствоүющїнХЬ. <325r>

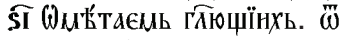

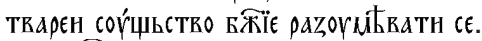

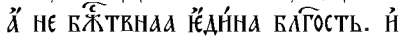

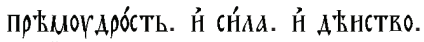

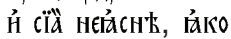
е́кно́щїю сьГиашающїнХь.

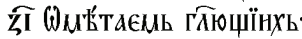

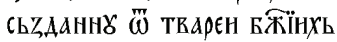

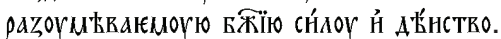

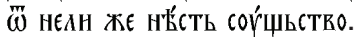

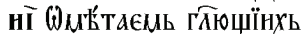

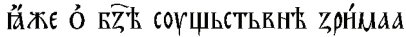

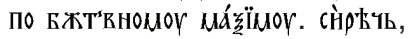

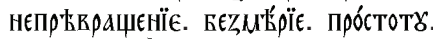
каГость. прТмогаро́сть. стость. Н́

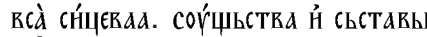

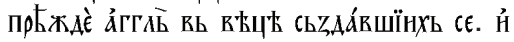

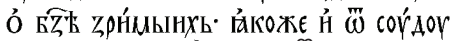

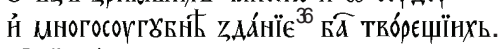

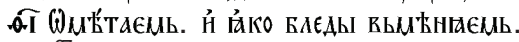

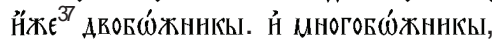

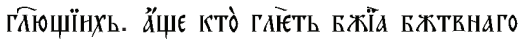

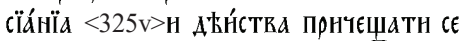

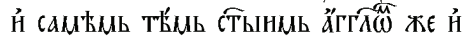

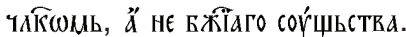

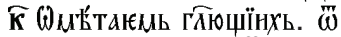

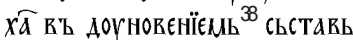

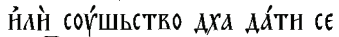

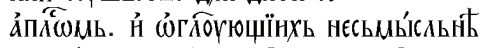

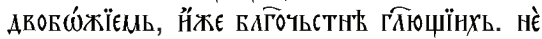

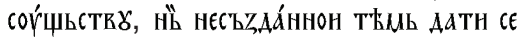

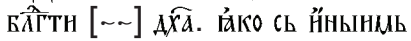

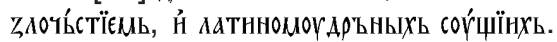

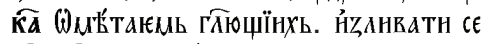

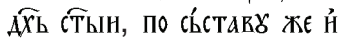

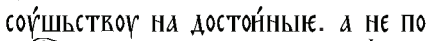

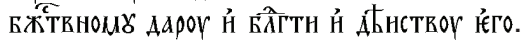

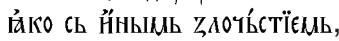

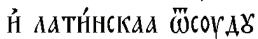

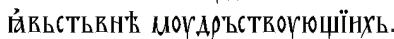

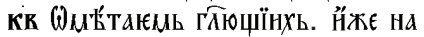

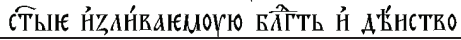

\footnotetext{
${ }^{36}$ ХАЗУ съz,а́́нїє

${ }^{37}$ ХАЗУ Ёжє

${ }^{38}$ ХАЗУ Аои́вєннієМь
} 


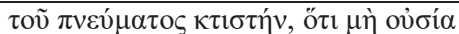

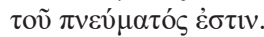

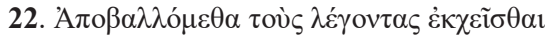

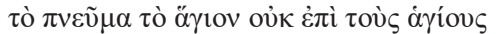

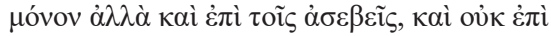

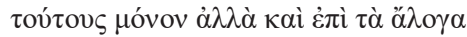

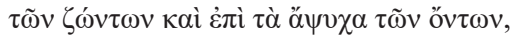

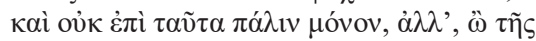

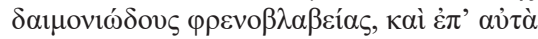
$\tau \grave{\alpha} \pi v \varepsilon u ́ \mu \alpha \tau \alpha \tau \tilde{\eta} \varsigma \pi 0 v \eta \rho i ́ \alpha \varsigma$.

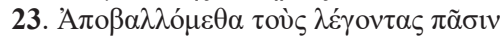

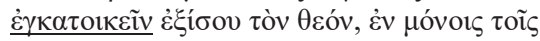

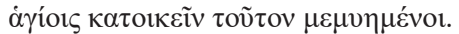

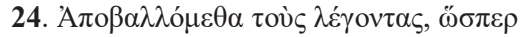

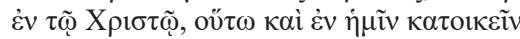

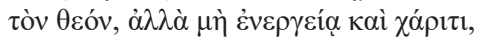

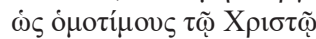

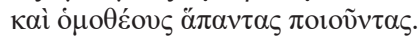

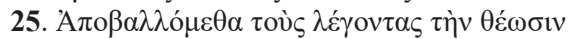

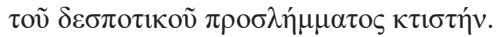

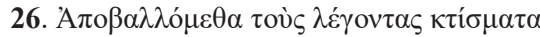

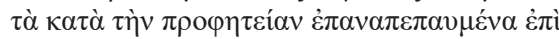

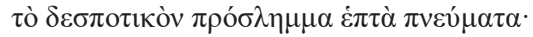

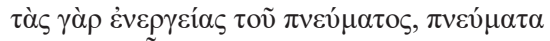

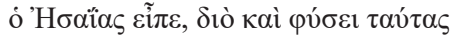

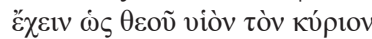
ó $\mu \alpha \kappa \alpha ́ \rho \operatorname{sos~\varepsilon ̌\varphi \eta ~Má\xi \xi \mu os.~}$

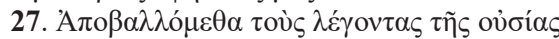

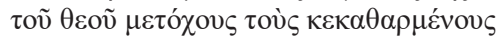

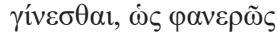

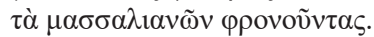

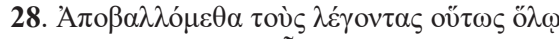

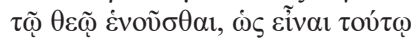

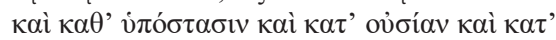

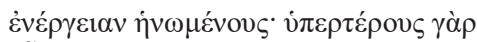

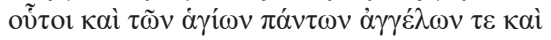

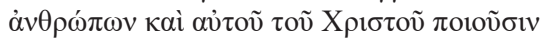

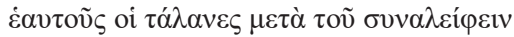

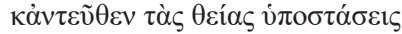

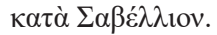

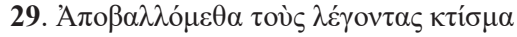

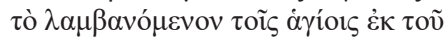

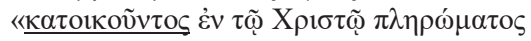

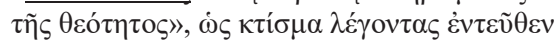

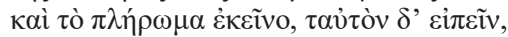

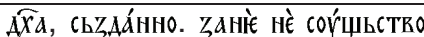

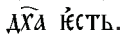

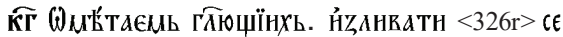

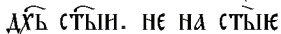

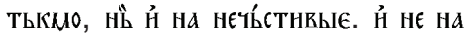

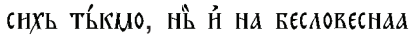

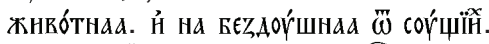

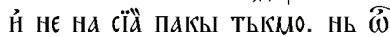

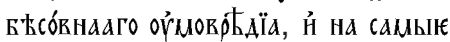

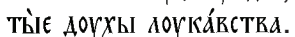

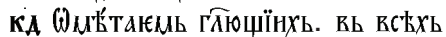

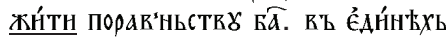

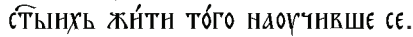

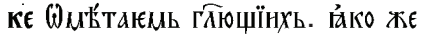

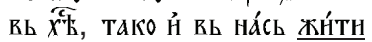

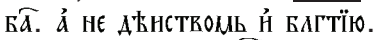

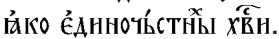

Н́ кькорпок

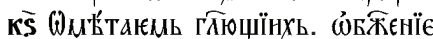

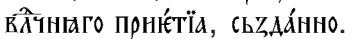

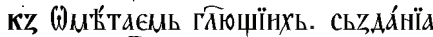

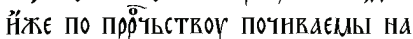

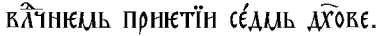

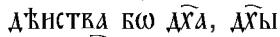

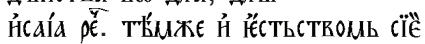

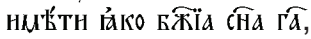

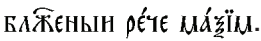

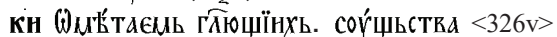

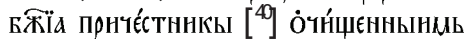
ки́Ік $А$ ТН. ஜ́ко ґ́кьстькнћ масалї́́нскаa моУ АрьсткоүющїнХь.

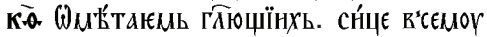

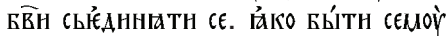

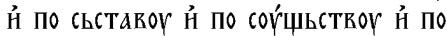

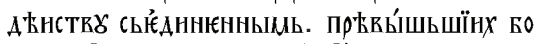

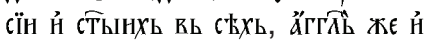

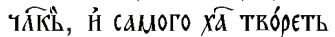

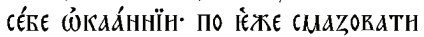

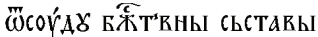
по саке́

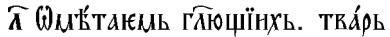

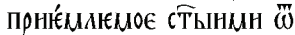

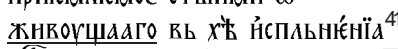

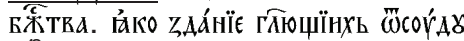

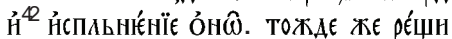

\footnotetext{
39 УБ вькои́повжт твнйї

40 XА3У म̉

41 УБ нспиьнгєнїє
} 


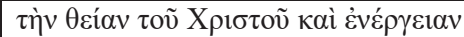

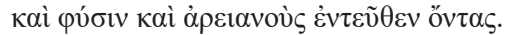

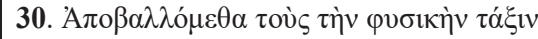

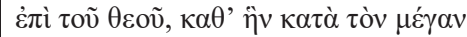

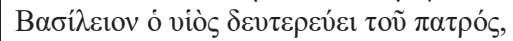

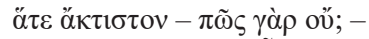

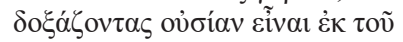

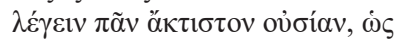

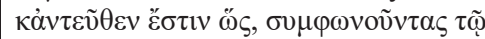

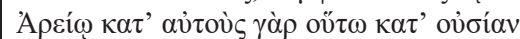

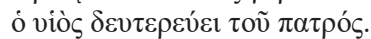

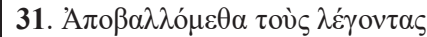

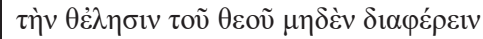

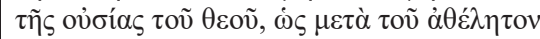

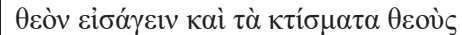

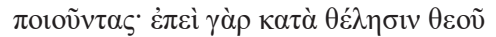

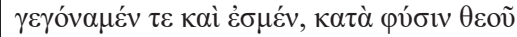

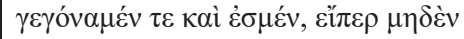

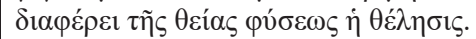

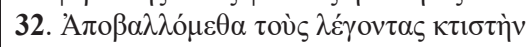

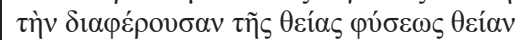

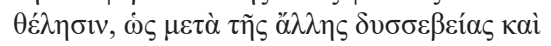

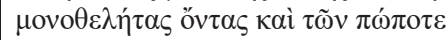

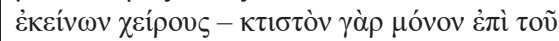

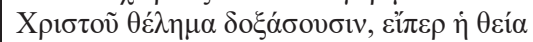

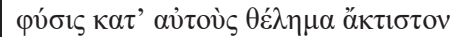

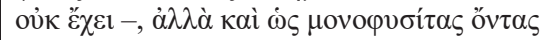

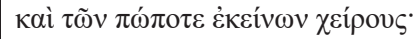

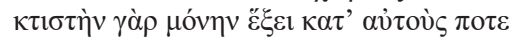

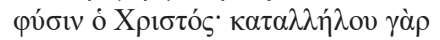

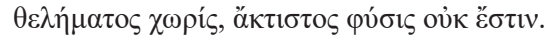

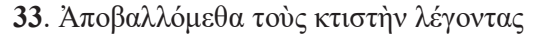

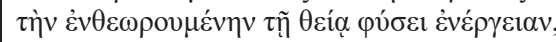

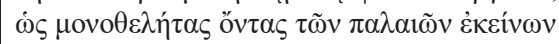

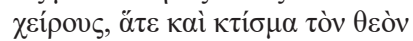

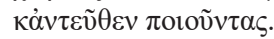

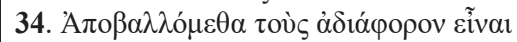

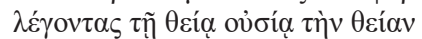

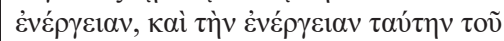

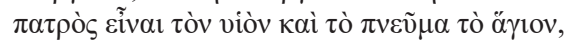

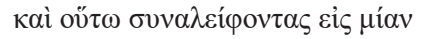

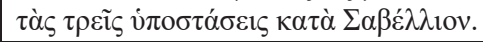

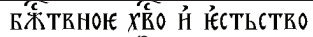

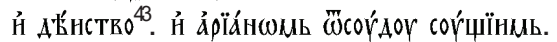

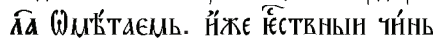

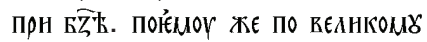

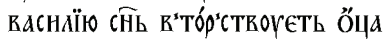

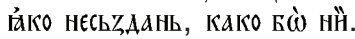

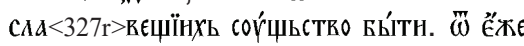

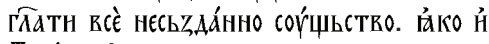

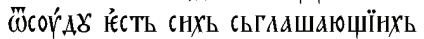

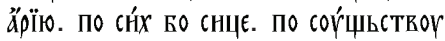

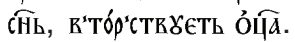

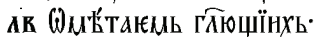

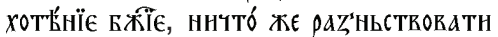

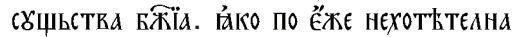

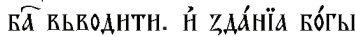

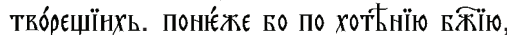

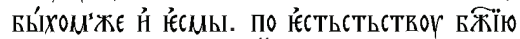

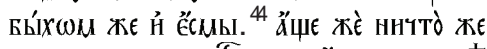

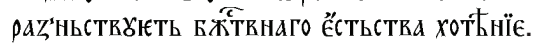

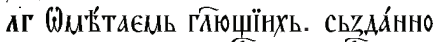

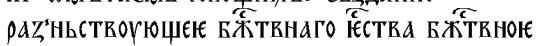

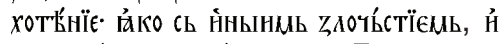

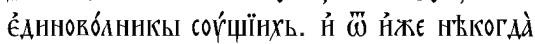

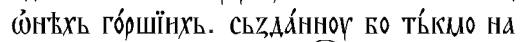

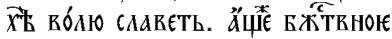

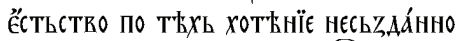

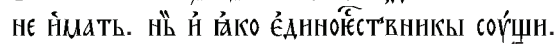

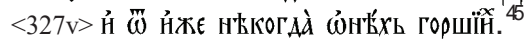

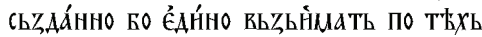

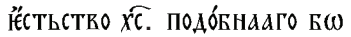

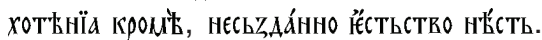

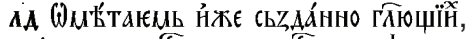

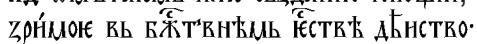

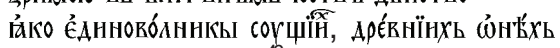

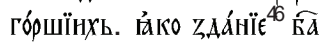

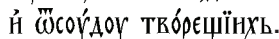

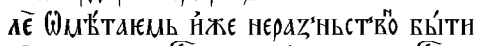

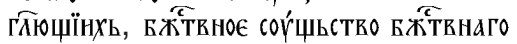

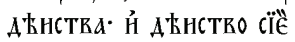

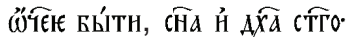

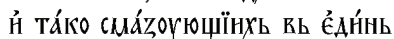

трй сьстакһ, по саке́Aї̈.

\footnotetext{
${ }^{42}$ УБ | ХАЗУ sine म̉

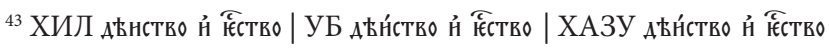

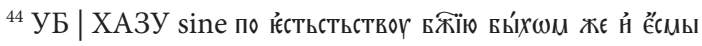

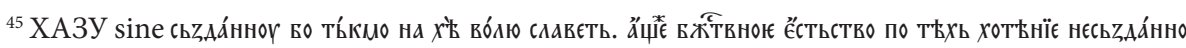

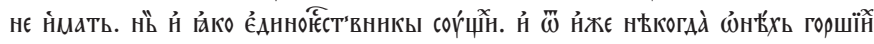

${ }^{46}$ ХАЗУ съz_а́́нїє
} 


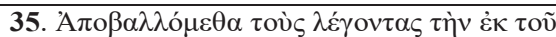

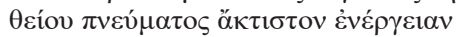

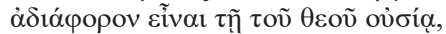

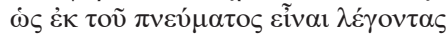

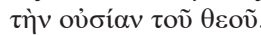

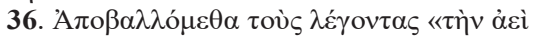

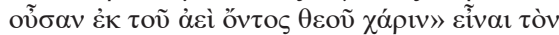

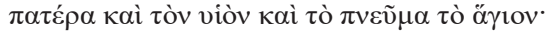

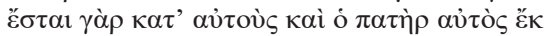

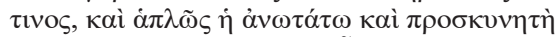

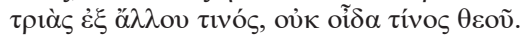

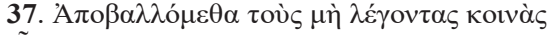

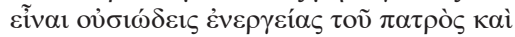

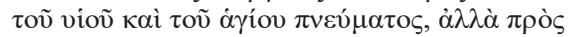

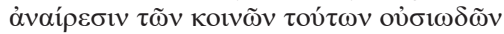

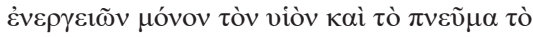

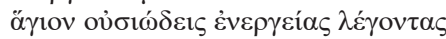

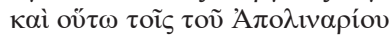

$\lambda$ ó

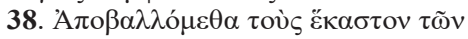

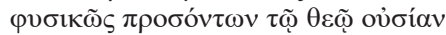

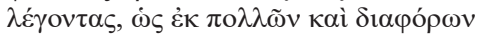

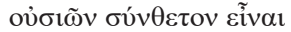

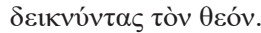

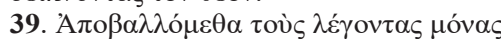

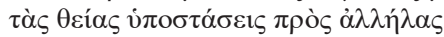

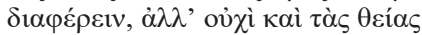

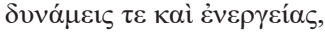

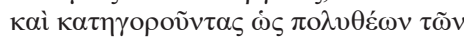

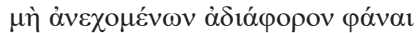

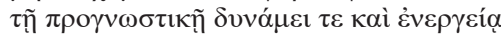

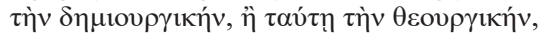

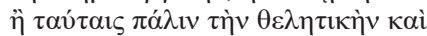

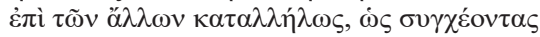

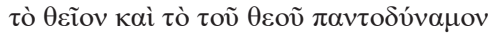

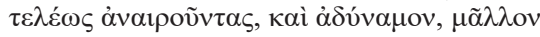

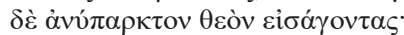

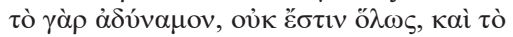
$\pi \tilde{\alpha} \varsigma \dot{\varepsilon} \pi \grave{\imath} \tau \tilde{\omega} \nu \dot{\alpha} \delta 1 \alpha \varphi \rho_{\rho} \omega v \pi \alpha v \tau \alpha \dot{\alpha} \pi \alpha \sigma \mathrm{v} v$

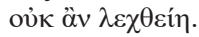

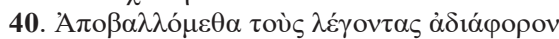

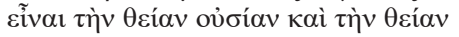

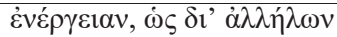

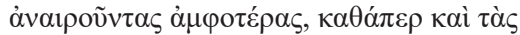

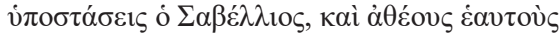

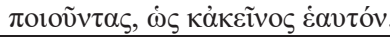

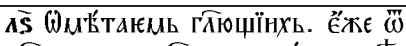

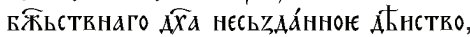

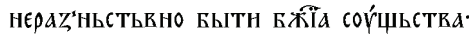

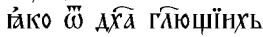

соү́шьство БЖё̈Е.

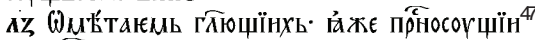

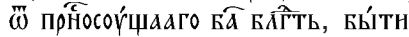

ळ̆

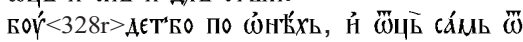

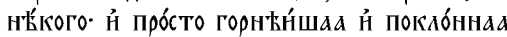
трон́ца, $\ddot{\omega}$ Н̈ного кого, некћдћ кото́радго Ба.

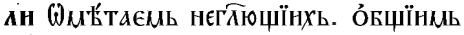

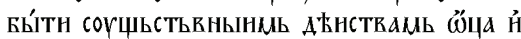

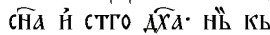

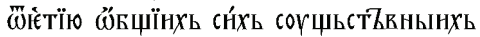

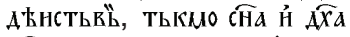

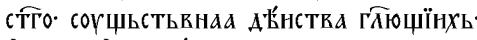

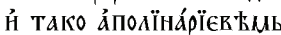
САОБЕСЕНЬ СЬГААШАЮШїНХЬ. ${ }^{48}$

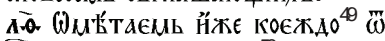

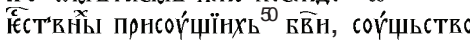

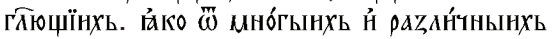

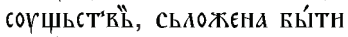
поки́zоүющїнхь Ка́.

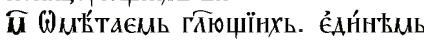

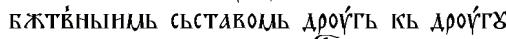

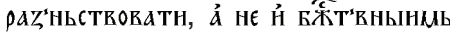

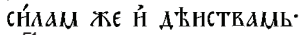

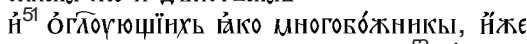

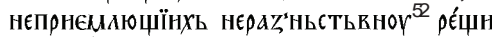
ПрОк $九$ А $<328 \mathrm{v}>$ ТЕ

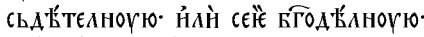

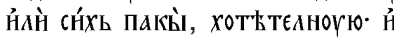

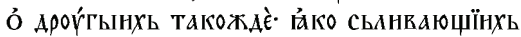

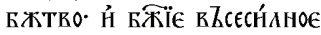

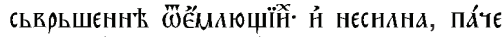

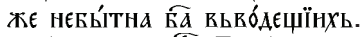
несн́

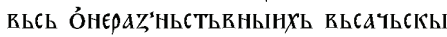

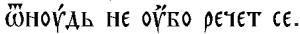

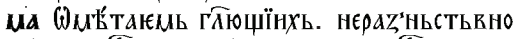

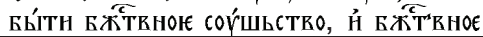

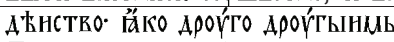

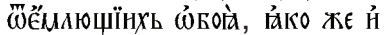

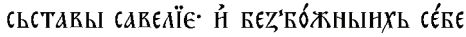

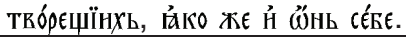

\footnotetext{
${ }^{47}$ ХАЗУ йкко прНОосои́щнїн

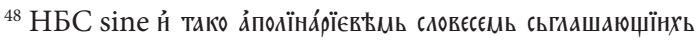

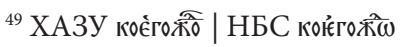

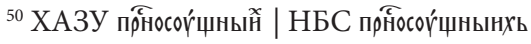

${ }^{51}$ ХАЗУ | НБС sine ${ }^{\circ}$

52 ХАЗУ нера́zньство् | НБС нера́żнаство्
} 
Philologia Mediana

\section{Изложење наопаког мноштва Варлаамових и Акиндинових злочести}

Одбацујемо најнечастивије и наопако мноштво Варлаамових и Акиндинових зловјерних догмата, као што ћемо оповргнути и сваки од њих понаособ.

1. Одбацујемо оне који, сагласно Варлааму и Акиндину, говоре да су у Богу два божанства, створено и нестворено, или уопште многа, те отуда надређена и подређена; али и оног који говори о самобитним ${ }^{53}$ нествореним, неједнаким и несличним међусобно по природи божанствима.

2. Одбацујемо оне који створеном на било који начин називају исијавајућу из Спаситеља на Тавору и од узишавших са њим [на гору] ученика неизрециво сагледавану свјетлост.

3. Одбацујемо оне који одричу и не славослове божанско и нестворено исијавање и благодат и енергију, већ [држе] да је она [та енергија] изнад сваке пројавности Божије суштаство, те оптужују оне који, осим изнад сваке пројавности суштаства, нествореним сматрају и то из њега исијавање на достојне, да тиме два заговарају божанства, надређено и подређено, не увиђајући да о нествореним

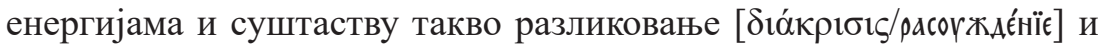
одговарајућа му надређеност [نं $\varepsilon \dot{\rho} \theta \varepsilon \sigma ı /$ прьложєнїє] не запречава да једно буде божанство, већ га штавише наглашава, пошто без њега није могуће саузвести у једно божанство оно што се благочестиво разликује.

4. Одбацујемо оне који све што се на било који начин разликује од Божијег суштаства називају створеним, као оне који свесилност Божију на творевину низвргавају, чинећи тако Бога творевином и сматрајући да су створени божанска промисао и божанско хтјење и божанско предзнање, као и са̂мо обожујуће исијавање, и овима слична.

\footnotetext{
${ }^{53}$ У току полемике са својим противницима, Григорије Палама је повремено наилазио на оптужбу за „платонизам“. Тако, рецимо, Никифор Григора (ŠOPEN 1855: 481-483) указује на сличност његовог учења о божанским енергијама и „учествовању“ са одговарајућим тезама новоплатоновца Прокла, док Григорије Акиндин паламитску доктрину представља као оживљавање платоновске теорије идеја. Повременом критиком „платонизама“ попут, рецимо, учења о стварању свијета из претпостојеће твари, учења о метемпсихози, постојању „космичке душе“ или, као у овом случају, учења о „самобитности“ енергија, које би се, у супротном, заиста могле довести у везу са платоновским „идејама“ Палама прави својеврсни отклон од таквог тумачења његових текстова. Ово питање свакако заслужује систематско истраживање, утолико прије што је „платоновско“ читање Паламиних текстова присутно и у модерној учености (в. IVANKA 1964: 389-445; FLOGAUS 1997; DEMETRAKOPULOS 2011).
} 
5. Одбацујемо оне који говоре да, као што се јавио Бог некима од старих у људском обличју, као старац или пак као младић, а божанско, опет, није ништа од тога, таква јесте и „свјетлост показавша божанство ученицима“" на гори, називајући [тако] свјетлост божанства привидом који нигдје уопште не постоји. ${ }^{54}$

6. Одбацујемо оне који кажу да је ту и такву свјетлост, створивши је на Таворској гори, Бог усвојио како би је вјечно имао на уживање праведницима, као оне који тврде да три природе сада има Господ наш Исус Христос: божанства, човјештва и те свјетлости, која пак није нити човјештва, нити, по овима, божанства; али и оне који говоре да два божанства отуда има Христос, једно истинско, а друго створено, и привидно, и лажноимено, и заиста на неблагочестив начин [схваћено] надређено и подређено. ${ }^{55}$

7. Одбацујемо оне који кажу да ова свјетлост и божанско и обожујуће сијање и благодат није нити створена нити нестворена, чиме сасвим потиру њено биће - јер оно што је нити створено нити нестворено уопште не бива -, али тиме и Бога [потиру], показавши се безбожнима: јер, оно што има такву благодат које нигдје и уопште нема, и само се казује лажноименим.

8. Одбацујемо оне који говоре да је ова свјетлост мање части и нижа од анђела и самих људских душа, тобоже стога што ови надилазе виђење.

9. Одбацујемо оне који говоре да лажу божанствени наши оци у пјесмама о свјетлости Господњег преображења и похвалама те пјесме називајући, као да тиме наводно прелазе границе истине, и опомињу нас да не прихватамо оно што је о тој свјетлости речено у светитељским похвалама, како нас то не би принуждило да поштујемо два божанства, надређено и подређено.

10. Одбацујемо као двобошце оне који самобожанство и богоначалство и доброначалство називају и створеним и нествореним. Пошто кажу да је и то богоначалство и доброначалство Божије створено,

\footnotetext{
${ }^{54}$ Божанска свјетлост и уопште божанске енергије не смију се схватити „алегоријски“. Штавише, Палама их (SINKEVIČ 1988: 170,230) изрично сврставау „бивствујућа“( а онда када их означава као „присуштности“ или „акциденције“, он то чини са оградом, подвлачећи да се оне - будући да се одликују перманентношћу и непромјенљивошћу - могу назвати „акциденцијама“ тек у преносном смислу: прецизније, оне су „квази-

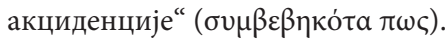

${ }^{55}$ Палама је сматрао да се о „надређеном“ и „подређеном“ божанству може говорити у a) „неблагочестивом“ смислу, то јест када се енергија божанског суштаства узима као сииворена, усљед чега се има посматрати као „подређена“ несиивореном божанском суштаству, и б) у побожном, благочестивом смислу, а то је када се тим (изворно Варлаамовим, како нас увјерава) појмовима указује како на јединстиво, тако и на разликоваюе унутар божанског бића (KNEŽEVIĆ, STOJANOVIĆ 2019: 206-212).
} 
одбацујемо их и стога што тиме Бога чине створењем, уистину бивајући безбожници и двобошци. ${ }^{56}$

11. Одбацујемо оне који говоре да силом божанског Духа не могу сагледавати ништа нестворено они што у Духу гледају, као оне који вријеђају саму ту силу божанског Духа. ${ }^{57}$

12. Одбацујемо оне који говоре да чак ни херувими и серафими не могу видјети било шта нестворено, као оне који и на тај начин чине Бога творевином: јер, „оно што је за чувствене [ствари] сунце, то је за умне [ствари] Бог"; ${ }^{68}$ а за вјечне анђеле, то јест за боговидиоце, он [Бог] је свјетлост, а не нешто друго.

13. Одбацујемо оне који кажу да, пошто је Бог прост [= несложен], није један његов дио схватљив, а други несхватљив, као сагласне Евномију.

14. Одбацујемо оне који говоре да је једино нестворено Божије суштаство, мислећи да све друго што светитељи називају божанством јесте створено божанство, и који за двобоштво оптужују оне који не само посве надимено суштаство, већ и надгледајућу Божију силу, и обожујућу и надзиратељну као и промислитељску, које се називају божанством, ${ }^{59}$ сматрају нестворенима.

15. Одбацујемо оне који кажу да се из створења̂ поима Божије суштаство, а не божанска сама доброта и мудрост и сила и енергија, па чак и ове нејасно, као сагласне Евномију.

16. Одбацујемо оне који говоре да је створена, из Божијих створења поимана, Божија сила и енергија, из разлога што није суштаство.

17. Одбацујемо оне који „суштаствено око Бога созерцаване [ствари]“, по божанском Максиму, „непромјенљивост, бесконачност, простоту,

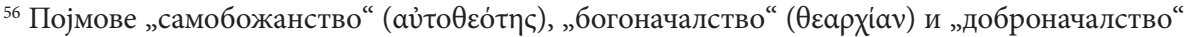
(à $\left.\alpha \theta \alpha \rho \chi^{i \alpha} \alpha\right)$ Палама преузима од Дионисија Псеудо-Ареопагита (HAJL, RITER 1990: 158).

${ }^{57}$ Мотив посредовања „силе“ Светог Духа приликом човјековог сагледавања божанских реалија сусреће се релативно често код Григорија Паламе, али и у гносеологији ранијих отаца. Тако, рецимо, у Паламиним Тријадама наилазимо на сљедеће карактеристично мјесто: „Не увиђаш ли, дакле, сада да умјесто ума, очију и ушију [они који сагледавају божанску свјетлост] имају несхватљивог Духа, којим и кроз којег виде, слушају и разумијевају? И заиста, када се заустави свака енергија ума, чиме виде анђели и равноанђелски људи Бога, ако не силом Духа““ (HRESTU 1962: 428.22-26; в. такође: HRESTU 1970: 271-273, 476.3-10; DE PLAS 1955: 88.13-15).

${ }^{58}$ Ова је метафора несумњиво платоновског поријекла, али је имала широку рецепцију у хришћанској литератури (в. SAFRI, VESTERINK 1974: VII, 48.24-26; Gregorii Theologi, Oratio XL, PG 36, 364B).

59 У склопу свог апофатичког приступа, сходног којем ниједно име - па чак ни име „божанство“ - не приличи Богу по себи, Палама на више мјеста тврди да се тим именом примарно означавају божанске енергиије, па тек онда - по њима - и „надсуштаствено Божије суштаство“ (HRESTU 1962: 664-665; HRESTU 1966: 231.12-27).
} 
доброту, мудрост, светост и све њима сличне, $6{ }^{60}$ називају суштаствима и ипостасима, прије анђела створенима у вјечности и созерцаванима око Бога, као оне које и тиме и многоструко Бога чине створењем.

18. Одбацујемо и клеветницима сматрамо оне који двобошцима и многобошцима називају оне који кажу да Божијем божанском сијању и енергији причаствују и сами свети анђели, као и људи, а не Божијем суштаству.

19. Одбацујемо оне који говоре да је из Христа удахнућем апостолима дата ипостас или суштаство Духа и који безумно оптужују за двобоштво благочестиво говореће да њима није дато суштаство, већ нестворена благодат божанског Духа, као, осим других злочести, и латиномислеће.

20. Одбацујемо оне који говоре да се излива Свети Дух по ипостаси и суштаству на достојне, а не по његовом божанском дару и благодати и енергији, као, осим других злочести, тиме очито и латиномислеће.

21. Одбацујемо оне који говоре да је благодат и енергија Духа, изливена на светитеље, створена, стога што није суштаство Духа.

22. Одбацујемо оне који говоре да се Свети Дух излива не само на светитеље, већ и на неблагочестиве, и не само на њих, већ и на бесловесне животиње и на нежива бића, и, опет, не само на ове, него - какве ли демонске неразумности - и на саме лукаве духове.

23. Одбацујемо оне који говоре да се у свима Бог настањује подједнако, поучени да он обитава само у светима.

24. Одбацујемо оне који говоре да у нама обитава Бог исто као и у Христу, а не енергијом и благодаћу, као оне који сваког чине равночасним Христу и равнобожним.

25. Одбацујемо оне који говоре да је обожење Владичиног усвојења створено. ${ }^{61}$

26. Одбацујемо оне који називају створенима седам по пророчанству на Господњем усвојењу почивајућих духова: јер, духовима је енергије Духа Исаија назвао, ${ }^{62}$ те је стога и блажени Максим рекао да ове по природи, као Божији Син, има Господ.

27. Одбацујемо оне који говоре да очишћени постају причасници Божијег суштаства, као оне који очигледно умују као месалијанци.

\footnotetext{
${ }^{60}$ Maximi Confessoris, Capita de caritate I, 100, PG 90, 984A; Capita theologica et oeconomica I, 48, PG 90, 1101B.

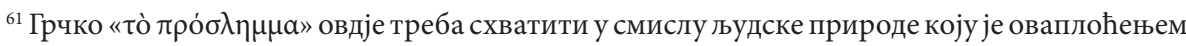
„усвојио“ Божији Логос.

62 Овај старозавјетни локус Палама евоцира релативно често (HRESTU 1966: 94.2-4; SINKEVIČ 1988: 164).
} 
28. Одбацујемо оне који кажу да се цјелосно сједињују са Богом тако што се са њим сједињују и по ипостаси и по суштаству и по енергији; јер, узвишенијим ови невољници од свих светих, анђела и људи, као и од самог Христа, себе чине, сливајући тако и божанске ипостаси, по узору на Савелија.

29. Одбацујемо оне који говоре да је створено [оно што је] од светитеља примљено из „обитавајуће у Христу пуноте божанства“, као оне који кажу да је тиме створена и та пунота или, другим ријечима, божанска Христова и енергија и природа, бивајући тако аријанцима. 30. Одбацујемо оне који природни поредак у Богу - сагласно којем, по великом Василију, Син јесте други у односу на Оца - сматрају, будући да је нестворен - јер, како не би био? - суштаством, ${ }^{63}$ тиме што кажу да све нестворено има бити суштаство, пошто је и отуда, по њима, сагласнима Арију, Син тако по суштаству други у односу на Оца.

31. Одбацујемо оне који говоре да се Божија воља ни по чему не разликује од Божијег суштаства, као оне који, поред тога што уводе Бога лишеног воље [å日ét боговима: пошто смо, дакле, по Божијој вољи настали и јесмо, по Божијој природи [испада да] смо настали и јесмо, ако се ни по чему не разликује воља од божанске природе.

32. Одбацујемо оне који називају створеном разликујућу се од божанске природе божанску вољу, као оне који су, поред других злочести, и монотелити гори и од оних негдашњих - зато што само створену у Христу вољу прихватају, пошто божанска природа, по њима, нема нестворену вољу -, али и као оне који су монофизити гори и од оних негдашњих, пошто ће само створену имати, по њима, природу Христос: јер, без одговарајуће [нестворене] воље, нема ни нестворене природе.

33. Одбацујемо оне који говоре да је створена у божанској природи созерцавана енергија, као монотелите горе од оних старих, пошто и тиме чине Бога створеним.

34. Одбацујемо оне који говоре да се божанска енергија не разликује од божанског суштаства и да та енергија Очева јесте Син и Свети Дух, сливајући тако три ипостаси у једну као Савелије.

35. Одбацујемо оне који говоре да из божанског Духа нестворена

\footnotetext{
${ }^{63}$ Паламино учење о нествореним енергијама карактеришу различите недосљедности и недоречености. Нарочито је нејасан однос „једне“ и „многих“ енергија, односно питање „Помногостручавања“ једне божанске енергије, али и то да ли Палама у категорију „бивствујућих“ уводи и „ипостасна својства“ или чак оно што је названо „поретком“ личности Свете Тројице. И ова тема изискује посебно истраживање. Питање „поретка“ ( $\left.\tau \dot{\alpha} \xi_{\iota \varsigma}\right)$ у домену тријадологије обрадио сам у посебној студији (KNEŽEVIĆ 2012).
} 
енергија није различита од Божијег суштаства, као оне који говоре да из Духа јесте Божије суштаство.

36. Одбацујемо оне који говоре да „свагда сушта из свагда суштег Бога благодат“ јесу Отац и Син и Свети Дух; јер, по њима ће и сам Отац бити из неког, и просто највиша и поштована Тројица [ће бити] из неког другог, ни сам не знам ког Бога.

37. Одбацујемо оне који одричу да заједничке јесу суштаствене

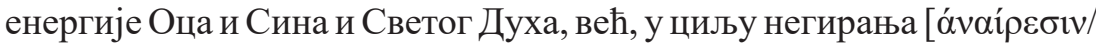
ஸ๋̋тїю] тих заједничких суштаствених енергија, само Сина и Светог Духа називају суштаственим енергијама, и тако се са Аполинаријевим ријечима саглашавајући.

38. Одбацујемо оне који говоре да је свако од природних својстава у Богу суштаство, као оне који Бога показују сложеног од многих и различитих суштастава.

39. Одбацујемо оне који говоре да се само божанске ипостаси међусобно разликују, али не и божанске силе и енергије, и који као многобошце оптужују оне што одбијају рећи да се стваралачка сила и енергија не разликује од прогностичке, или пак од ње богодјелатна, или опет од ових вољна, и остале међусобно; [одбацујемо их] као оне који сливају божанско и Божију свесилност сасвим поништавају, и уводе недјелатног, тачније, непостојећег Бога: јер, оно што је недјелатно уопште не постоји, а „све“64 о сасвим неразликов(а)нима не може се рећи.

40. Одбацујемо оне који говоре да се не разликују божанско суштаство и божанска енергија, као оне који их једно кроз друго поништавају, као што је и ипостаси [поништавао] Савелије, и који себе чине безбожнима, као што је и онај себе.

\section{Цитирана литература}

CERNIĆ 1981: CERNIĆ, Lucija. „O atribuciji srednjovekovnih srpskih ćirilskih rukopisa“, u: BOGDANOVIĆ, Dimitrije (ur.). Zbornik radova sa Međunarodnog naučnog skupa ,, Tekstologija srednjovekovnih južnoslovenskih književnosti", 14-16. novembra 1977, Beograd: Srpska akademija nauka i umetnosti 1981, 335-424. [orig.] ЦЕРНИЋ, Луција. „О атрибуцији средњовековних српских ћирилских рукописа“, у: БОГДАНОВИЋ, Димитрије (ур.). Зборник радова са Међународног научног скупа „Тексто-

\footnotetext{
${ }^{64}$ Мисли се на „све“ у ријечи „свесилно“. Пошто је Бог у патристичкој литератури

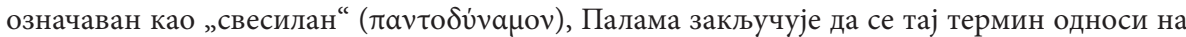

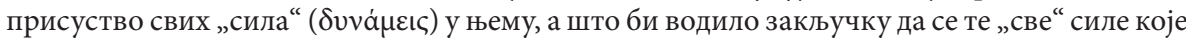
су у Богу - будући „све“ - имају међусобно разликовати.
} 
логија средњовековних јужнословенских књижевности“, 14-16. новембра 1977, уредник Димитрије Богдановић, Београд: Српска академија наука и уметности 1981, 335-424.

DANIČIĆ 1869: DANIČIĆ, Đuro. „Rukopis Vladislava Gramatika pisan godine 1469“, Starine I (1869): str. 44-85. [orig.] ДАНИЧИЋ, Ђуро. „Рукопис Владислава Граматика писан године 1469“, Старине I (1869): стр. 44-85.

DARUZE 1963: DARROUZÈS, Jean. « Le mémoire de Constantin Stilbès contre les Latins », Revue des études byzantines 21 (1963): str. 50-100.

DEMETRAKOPULOS 2011: DEMETRACOPOULOS, John A. "Palamas Transformed. Palamite Interpretations of the Distinction between God's 'Essence' and 'Energies' in Late Byzantium', y: HINTERBERGER, M. SCHABEL, Ch. (ed.) Greeks, Latins, and Intellectual History 1204-1500, Bibliotheca 11, Leuven, Paris, Walpole, MA: Peeters 2011, 263-372.

DURKOVIĆ-JAKŠIĆ 1957: DURKOVIĆ-JAKŠIĆ， Ljubomir. „Knjižnica manastira Svete Trojice kod Pljevalja“, Bibliotekar IX, 3-4 (1957): str. 227 234. [orig.] ДУРКОВИЋ-ЈАКШИЋ, Љубомир. „Књижница манастира Свете Тројице код Пљеваља“, Библиотекар IX, 3-4 (1957) 227-234.

ERIKSON 1970: ERICKSON, John. "Leavened and Unleavened: Some Theological Implications of the Schism of 1054", St Vladimir's Theological Quarterly 14 (1970): str. 155-176.'

FLOGAUS 1997: FLOGAUS, Reinhard. Theosis bei Palamas und Luther. Ein Beitrag zum ökumenischen Gespräch, Forschungen zur systematischen und ökumenischen Theologie 78, Göttingen: Vandenhoeck \& Ruprecht in Göttingen 1997.

IVANKA 1964: IVANKA, Endre von. Plato Christianus. Übernahme und Umgestaltung des Platonismus durch die Väter, Einsiedeln: Johannes Verlag $1964,{ }^{2} 1990$.

IVANOVA 1985: IVANOVA, Klimentina. „Klasifikatsiya, tipologiya i katalogizatsiya na nyakoi tipove sbornitsi v balkanskata slvyanska rakopisna traditsiya“, u: Slavyanska paleografiya i diplomatika. 2. Lektsii ot Vtoriya seminar po paleografiya $i$ diplomatika, Sofiya, avgust 1983, SIBAL, Balkanica III. Études et documents, 4, Sofiya 1985, 173-182. [orig.] ИВAНОВА, Климентина. „Класификация, типология и каталогизация на някои типове сборници в балканската слвянска ръкописна традиция“, у: Славянска палеография и дипломатика. 2. Лекиии от Втория семинар по палеография и дипломатика, София, август 1983, СИБАЛ, Balkanica III. Études et documents, 4, София 1985, 173-182.

JEVTIĆ 1994: JEVTIĆ, A tanasije. „Susret sholastike i isihazma kod Nila Kavasile“, u: Episkop Atanasije, Filosofija i teologija, Vrnjačka Banja: Bratstvo Sv. Simeona Mirotočivog 1994, 11-28. [orig.] ЈЕВТИЋ, Атанасије. „Сусрет схоластике и исихазма код Нила Кавасиле“, у: Епископ Атанасије, Философија и теологија, Врњачка Бања: Братство Св. Симеона Мироточивог 1994, 11-28. 
JEVTIĆ 2013: JEVTIĆ, Atanasije. „Ispovedanje vere Svetog Grigorija Palame - srpski prevod u Pećskom rukopisu 85 iz 1353. godine“, u: KNEŽEVIĆ, Mikonja (prir.). Ousia, hypostasis, energeia. Aspekti misli Grigorija Palame, Beograd: Institut za teološka istraživanja 2013, 509-523. [orig.] JЕВТИЋ, Атанасије. „Исповедање вере Светог Григорија Паламе - српски превод у Пећском рукопису 85 из 1353. године“, у: КНЕЖЕВИЋ, Микоња

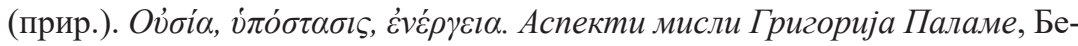
оград: Институт за теолошка истраживања 2013, 509-523.

KAKRIDIS, TASEVA 2014: KAKRIDIS, Yannis. TASEVA, Lora. Gegen die Lateiner Traktate von Gregorios Palamas und Barlaam von Kalabrien in kirchenslavischer Übersetzung, Weiher, Freiburg i. Br. Hubert \& Co. 2014.

KAKRIDIS 2019: KAKRIDIS, Janis. Argumentacija kod pravoslavnih Slovena $u$ srednjem veku, Niš: Međunarodni centar za pravoslavne studije, Centar za vizantijsko-slovenske studije Univerziteta u Nišu 2019. [orig.] КАКРИДИС, Јанис. Аргументација код православних Словена у средњем веку, Ниш: Међународни центар за православне студије, Центар за византијско-словенске студије Универзитета у Нишу 2019.

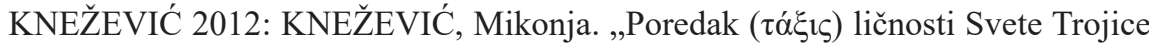
u 'Apodiktičkim slovima' Grigorija Palame“, Bogoslovlje LXX, 1 (2011): str. 20-43. [orig.] КНЕЖЕВИЋ, Микоња. „Поредак ( $\tau \alpha \dot{\xi} \xi \varsigma)$ личности Свете Тројице у’Аподиктичким словима' Григорија Паламе“, Богословље LXX, 1 (2011): стр. 20-43.

KNEŽEVIĆ, STOJANOVIĆ 2019: KNEŽEVIĆ, Mikonja. STOJANOVIĆ, Jelica. „Poslanica Ani Paleologini Grigorija Palame (uz izdanje srpskoslovenskog prevoda iz Zbornika 41 Manastira Svete Trojice kod Pljevalja)“, Zbornik radova Vizantološkog instituta 56 (2019): str. 197-231. [orig.] КНЕЖЕВИЋ, Микоња. СТОЈАНОВИЋ, Јелица. „Посланица Ани Палеологини Григорија Паламе (уз издање српскословенског превода из Зборника $41 \mathrm{Ma-}$ настира Свете Тројице код Пљеваља)“, Зборник радова Византолошког института 56 (2019): стр. 197-231.

KOSANOVIĆ 1871: KOSANOVIĆ, Sava. „Srpske starine u Bosni. Nekolike bilješke“, Glasnik Srpskog učenog društva XII [XXIX] (1871): 158-188. [orig.] КОСАНОВИЋ, Сава. „Српске старине у Босни. Неколике биљешке“, Гласник Српског ученог друштва XII [XXIX] (1871): 158-188.

LAZIĆ 1999: LAZIĆ, Milorad. Isihazam srpske knjige, Niš: Prosveta 1999. [orig.] ЛАЗИЋ, Милорад. Исихазам српске књиге, Ниш: Просвета 1999.

MOŠIN 1955: MOŠIN, Vladimir. Ćirilski rukopisi Jugoslavenske akademije, I-II, Zagreb: Jugoslavenska akademija znanosti i umjetnosti 1955.

MOŠIN 1958: MOŠIN, Vladimir. „Ćirilski rukopisi manastira sv. Trojice kod Pljevalja“", Istoriski zapisi XIV, 1-2 (1958): str. 235-260. [orig.] МОШИН, Владимир. „һирилски рукописи манастира св. Тројице код Пљеваља“, Историски записи XIV, 1-2 (1958): стр. 235-260. 
PASHALIDES 1999: PASCHALIDĒS, Symeōn A. Nikētas Dabid Paphlagōn. Tó prosōpo kai to ergo tou. Symbolè stè meletē tēs prosōpographias kai tès hagiologikès grammateias tès prometaphrastikēs periodou, Byzantina Keimena kai Meletai 28, Thessaloníkē: Kentro Byzantinōn Ereunōn 1999.

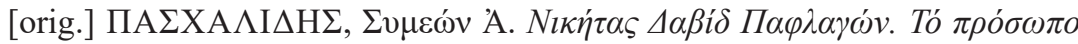

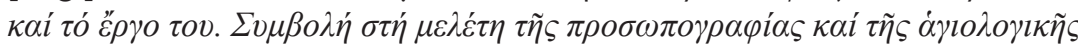

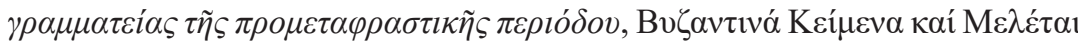

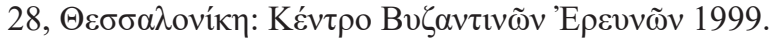

PETKOVIĆ 2008: PETKOVIĆ, Sreten. Manastir Cveta Trojica u Pljevljima, drugo, dopunjeno izdanje, Pljevlja: Zavičajni muzej 2008. [orig.] ПЕТКОВИЋ, Сретен. Манастир Света Тројица у Пљевљима, друго, допуњено издање, Пљевља: Завичајни музеј 2008.

PUZOVIĆ, NIKOLIĆ 2014: PUZOVIĆ, Vladislav. NIKOLIĆ, Bogdana. „Antiohijski patrijarh Petar III (1052-1056) i crkvena kriza 1054. godine“, Zbornik radova Vizantološkog instituta LI (2014) 71-92. [orig.] ПУЗОВИЋ, Владислав. НИКОЛИЋ, Богдана. „Антиохијски патријарх Петар III (1052-1056) и црквена криза 1054. године“, Зборник радова Византолошког института LI (2014) 71-92.

RADOJIČIĆ 1949: RADOJIČIĆ, Đorđe. „Izveštaj o putu u manastir Svete Trojice kod Pljevalja i u manastir Ljubostinju“, Glasnik SAN I, 1-2 (1949): str. 220-227. [orig.] РАДОЈИЧИЋ, Ђорђе. „Извештај о путу у манастир Свете Тројице код Пљеваља и у манастир Љубостињу“, Гласник САН I, 1-2 (1949): 220-227.

RADUNOVIĆ 1998: RADUNOVIĆ, Veljko. Ta erga tou Agiou Grēgoríou Palama stē serbikē grammateia tou 14 ou aiōna, diatribē pou ypoblēthēke sto Tmēma Theologías tēs Theologikēs Scholēs tou A.P.Th, Theologikē Scholē tou Aristoteleiou Panepistēmiou Thessalonikēs, Thessalonikē 1998. [orig.]

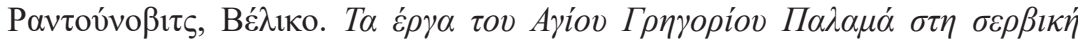

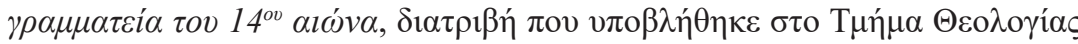

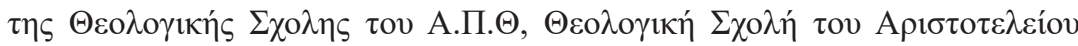

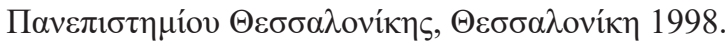

RANKOVIĆ 2013: RANKOVIĆ, Zoran. „Književna dela sv. Grigorija Palame u srpskoslovenskoj rukopisnoj tradiciji“, u: KNEŽEVIĆ, Mikonja (prir.). Ousia, hypostasis, energeia. Aspekti misli Grigorija Palame, Beograd: Institut za teološka istraživanja 2013, 501-508. [orig.] РАНКОВИЋ, Зоран. „Књижевна дела св. Григорија Паламе у српскословенској рукописној тради-

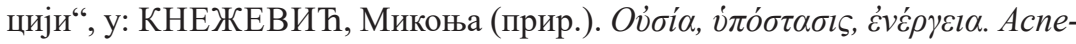
кти мисли Григорија Паламе, Београд: Институт за теолошка истраживања 2013, 501-508.

SINKEVIČ 2002: SINKEWICZ, Robert. "Gregory Palamas. II. Works. V. Bibliography”, y: CONTICELLO, C. G. CONTICELLO, V. (éd.). La théologie Byzantine et sa tradition, II (XIII ${ }^{e}-X I X^{e}$ s.), sous la direction de Corpus Christianorum. Centre d'études des religions du livre, Turnhout: Brepols 2002 138-155, 173-188. 
SKARPA 2012: SCARPA, Marco. Gregorio Palamas Slavo. La tradizione manoscritta delle opere. Recensione dei codici, Milano: Edizioni Biblion 2012.

SKARPA 2014: SKARPA, Marko. «Slavjanskij perevod tvorenija Nila Kavasily: novyj vzgljad na podlinnik», u: Afon i slavjanskij mir. Sbornik 1 Materialy mezhdunarodnoj nauchnoj konferencii, posvjashhennoj 1000-letiju prisutstvija russkih na Svjatoj Gore, Belgrad, 16-18 maja 2013. g., Svjataja Gora Afon: Izdanie Russkogo Svjato-Panteleimonova monastyrja na Afone 2014, 256-261. [orig.] СКАРПА, Марко. «Славянский перевод творения Нила Кавасилы: новый взгляд на подлинник», у: Афон и славянский мир. Сборник 1 Материалы международной научной конференщии, посвященной 1000-летию присутствия русских на Святой Горе, Белград, 16-18 мая 2013. г., Святая Гора Афон: Издание Русского Свято-Пантелеимонова монастыря на Афоне 2014, 256-261.

STANKOVIĆ 2003: STANKOVIĆ, Radoman. Rukopisne knjige manastira Svete Trojice kod Pljevalja. Vodeni znaci $i$ datiranje, Narodna biblioteka Srbije. Opis južnoslovenskih ćirilskih rukopisa. Tom VI, Narodna biblioteka Srbije, Beograd 2003. [orig.] СТАНКОВИЋ, Радоман. Рукописне књиге манастира Свете Тројице код Пљеваљь. Водени знаци и датирање, Народна библиотека Србије. Опис јужнословенских ћирилских рукописа. Том VI, Народна библиотека Србије, Београд 2003.

VUKIĆEVIĆ 1901: VUKIĆEVIĆ, Mil. M. „Iz starih Srbulja“, Glasnik Zemaljskog muzeja u Bosni i Hercegovini XIII, 2-3 (1901): str. 289-349. [orig.] ВУКИЋЕВИЋ, Мил. М. „Из старих Србуља“, Гласник Земаљског музеја у Босни и Херчеговини ХІІІ, 2-3 (1901): стр. 289-349.

ŽUNJIĆ 2013: ŽUNJIĆ, Slobodan. „Protivlatinske i isihastičke rasprave u srednjovekovnoj srpskoj filozofiji“", u: KNEŽEVIĆ, Mikonja (prir.). Ousia, hypostasis, energeia. Aspekti misli Grigorija Palame, Beograd: Institut za teološka istraživanja 2013, 524-571. [orig.] ЖУЮИЋ, Слободан. „Противлатинске и исихастичке расправе у средњовековној српској фило-

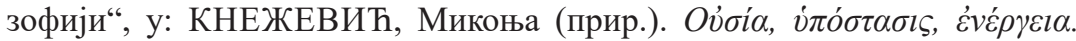
Аспекти мисли Григорија Паламе, Београд: Институт за теолошка истраживања 2013, 524-571.

\section{Извори}

ANTON 1924-1930: ANTON, Michel. Humbert und Kerullarios, I-II, Quellen und Forschungen aus dem Gebiet der Geschichte 21, 23, Paderborn: F. Schöningh 1924-1930.

DEMETRAKOPULOS 1866: DĒMĒTROKOPOULOU, A. K. (ed.). Ekklēsiastikē bibliothēkē, emperiekhousa Hellēnōn theologōn syngrammata, ek kheirographōn tēs en Moskha bibliothēkēs nyn prōton ekdidomena 
hypo arkhimandritou Andronikou K. Dēmētrokopoulou, tómos $\mathrm{A}^{\prime}$, en

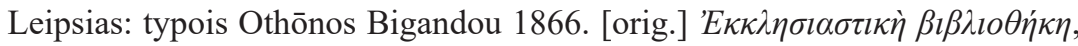

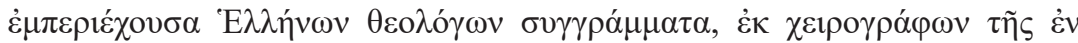

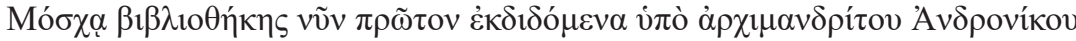

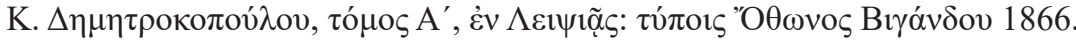

DE PLAS 1955: DES PLACES, Édouard (ed.). Diadoque de Photicé, Euvres spirituelles. Introduction, texte critique, traduction et notes de Édouard des Places, Paris: Les Éditions du Cerf 1955.

DUNAEV 2009: DUNAEV, A. G. (ed.). Svjatitel' Grigorij Palama, Arhiepiskop Fessalonikijskij, Polemika s Akindinom, izdanie podgotovil A. G. Dunaev, Svjataja gora Afon: Izdanie pustyni Novaja Fivaida Afonskogo Russkogo Panteleimonova monastyrja 2009. [orig.] Святитель Григорий Палама, Apхиепископ Фессалоникийский, Полемика с Акиндином, издание подготовил А. Г. Дунаев, Святая гора Афон: Издание пустыни Новая Фиваида Афонского Русского Пантелеимонова монастыря 2009.

HAJL, RITER 1990: HEIL, Günter. RITTER, Adolf Martin (ed.). Corpus Dionysiacum II. De Coelesti Hierarchia, De Ecclesiastica Hierarchia, De Mystica Theologia, Epistulae. Herausgegeben von Günter Heil und Adolf Martin Ritter, Patristische Texte und Studien 26, Berlin: Walter de Gruyter 1990.

HRESTU 1962: CHRĒSTOU, Panagyotēs (ed.). Grēgoriou tou Palama Syngrammata. Ekdidontai epimeleia P. K. Chrēstou. Tomos 1. Logoi apodeiktikoi. Antepigraphai. Epistolai pros Barlaam kai Akindynon. Hyper hēsychazontōn. Ekdidoun B. Bobrinsky, P. Papaeuangelou, I. Meyendorff, P. Chrēstou, Thessalonikē: Kyromanos 1962, ${ }^{2} 1988$. [orig.] Г

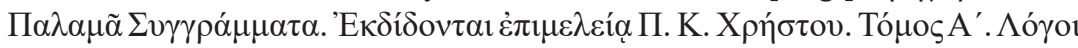

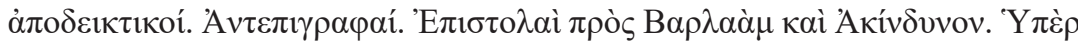

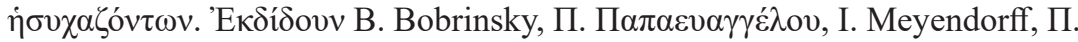

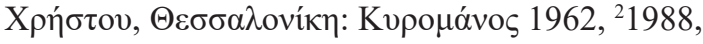

HRESTU 1966: CHRĒSTOU, Panagyotēs (ed.). Grēgoriou tou Palama Syngrammata. Ekdidontai epimeleia P. K. Chrēstou. Tomos 2. Pragmateiai kai epistolai grapheisai kata ta etē 1340-1346. Prologizei P. Chrēstou. Ekdidoun G. Mantzaridēs, N. Matsoukas, B. Pseutonkas, Thessalonikē: Kyromanos

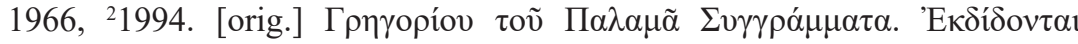

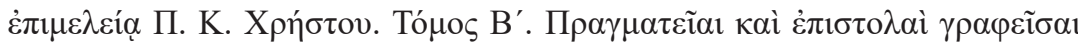

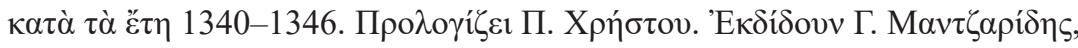

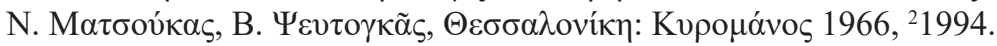

HRESTU 1970: CHRĒSTOU, Panagyotēs (ed.). Grēgoríou tou Palama Syngrammata. Ekdidontai epimeleia P. K. Chrēstou. Tomos 3. Antirrhētikoi pros Akindynon. Prologizei P. Chrēstou. Ekdidoun L. Kontogiannēs. B. Phanourgakēs, Thessalonikē: Kyromanos 1970. [orig.] Г $ү \gamma о \rho i ́ o v ~ \tau o v ̃ ~ П \alpha \lambda \alpha \mu \tilde{\alpha}$

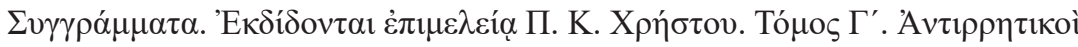

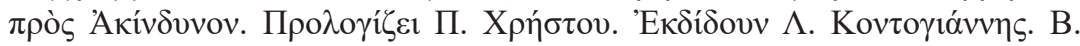

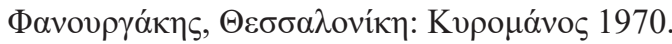


KOLBABA 1995: KOLBABA, Tia. "Barlaam the Calabrian. Three Treatises on Papal Primacy, Introduction, Edition, and Translation", Revue des études byzantines 53 (1995): str. 41-115.

PAVLOV 1878: Kriticheskie opyti po istorii drevnrojshej greko-russkoj polemiki protiv Latinjan', S.-Peterburg: Tipografija Imperatorskoj Akademii nauk' 1878. [orig.] ПАВЛОВ, А. Критическіе опьті по исторіи древнгйшей греко-русской полемики против Латинянъ, С.-Петербургъ: Типографія Императорской Академіи наукъ 1878.

PHILOKALIA 1782: Philokalia tōn hierōn nēptikōn syneranistheisa para tōn hagiōn kai theophorōn paterōn hēmōn, en hè dia tès kata tēn praxin kai theōrian èthikēs philosophias ho nous kathairetai, phōtizetai kai teleioutai. Epimeleia, men hoti pleistē, diorthōtheisa nyn de prōton typois ekdotheisa dia dapanēs tou timiōtatou, kai theosebestatou kyriou Iōannou Maurogordatou eis koinēn tōn orthodoxōn ōpheleian Para Antōniō tō Bortoli. Con licenza de' superiori, e privilegio,

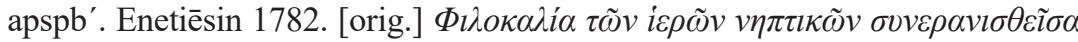

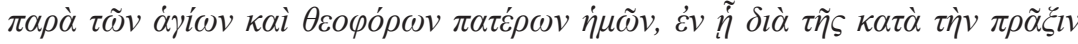

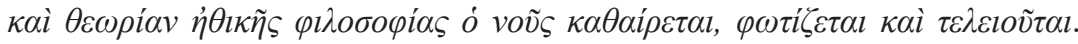

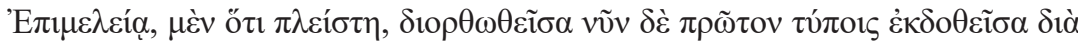

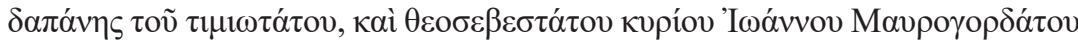

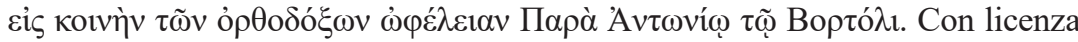

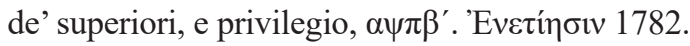

SAFRI, VESTERINK 1974: SAFFREY, Henri Dominique. WESTERINK, Leendert Gerrit (ed.). Proclus, Théologie Platonicienne, Livre II, édited par Henri Dominique Saffrey, Leendert Gerrit Westerink, Collection des Universites de France, Paris: Les Belles Lettres 1974.

ŠOPEN 1855: SCHOPEN, Ludwig (ed.). Nicephori Gregorae Byzantina Historia, graece et latine, cum annotationibus Hier. Wolfii, Car. Ducangii, Io. Boivini et Cl. Capperonnerii, cura L. Schopeni, III, Impensis ed Weberi, Bonnae MDCCCLV.

SINKEVIČ 1988: SINKEWICZ, Robert E. (ed.). Saint Gregory Palamas. The One Hundred and Fifty Chapters. A Critical Edition, Translation and Study by Robert E. Sinkewicz, Studies and Texts 83, Toronto: Pontifical Institute of Mediaeval Studies 1988.

TOMOS AGAPES 1698: Tomos agapēs kata Latinōn syllegeis kai typotheis para Dositheou Patriarchou Hierosolymōn. Epi tēs hēgemonias tou eusebestatou kai eklamprotatou authentos kai hēgemonos kyriou Iōannou Antiochou Kōnstantinou boeboda pasēs Moldoblachias. Etypōsamen ton paranta tomon en Giasiō tēs Moldoblachias, khalkotypia kai analōmasi tou hagiou taphou dia Dionysiou monachou, ontos diorthōtou tou logiōtatou didaskalou Hieremia tou Kakkabela. Ei de kai eisi sphalmata eis tina grammata $\overline{\mathrm{e}}$ lexeis, touto symbebēke dia to einai ton khalkographon heteroglōsson kai mē eidita Hellēnika grammata; kai loipon estō syngnōmē. En etei tō sōtēriō 1698 mēni Martiō. [orig.] Tó

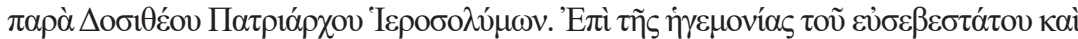




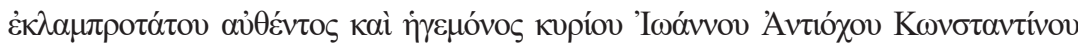

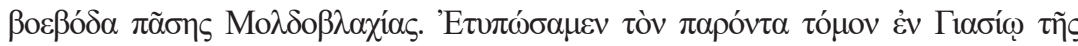

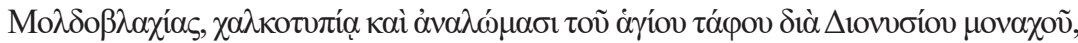

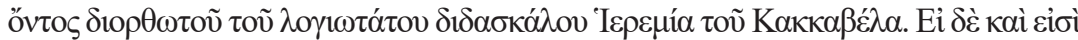

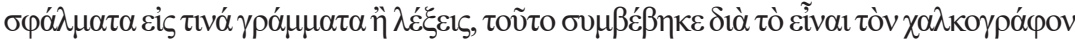

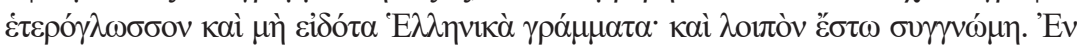

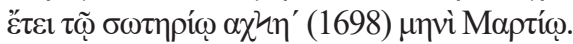

VALTER 1899: WALTER, Carolus (ed.). Ioannis Philoponi, Libellus de Paschate, edidit et praefatione ornavit Carolus Walter, Lipsiae: Typis B. G. Teubneri MDCCCXCIX, 209-222.

VIL 1861: WILL, Cornelius (ed.). Acta et Scripta quae de controversiis ecclesiae Graeca et Latinae saeculo undecimo composita extant ex probatissimis libris emendatora edidit diversitatem lectionis enotavit annotationibus instruxit Dr. Cornelius Will, Lipsiae et Marpurgi: Sumptibus N. G. Elwerti bibliopolae academica MDCCCLXI.

Mikonja Knežević

\title{
PALAMAS'S EXPOSITION OF THE EXTRAORDINARY MULTITUDE OF THE IMPIETIES OF BARLAAM AND AKINDYNOS. SERBO-SLAVONIC TRANSLATION FROM THE CODEX 41 OF THE MONASTERY OF THE HOLY TRINITY OF PLJEVLJA
}

\begin{abstract}
Summary: Gregory Palamas's work Exposition of the Extraordinary Multitude of the Impieties of Barlaam and Akindynos was written ca. 1344. In the course of polemics with his former pupil, Gregory Akindynos, Palamas conducted this short treatise, into which he enlisted 40 "haeresies" of his ideological opponents. Along with some other Palamas's works - such are Apodictic Treatises on the Procession of the Holy Spirit, Contra Bekkos, On Divine Unity and Distinction, Confession of Faith, Exposition of Impities of Barlaam and Akindynos - this short treatise was also translated into Serbian Church Slavonic language, most probably in the final quartal of the 14th century.

In this paper the Serbo-slavonic translation of Palamas's Exposition is given, along with the Greek original and its translation into Modern Serbian. The basic text is the fifth, until now unknown Serbo-slavonic transcription of the Exposition, which I discovered in Codex 41 of the Monastery of the Holy Trinity of Pljevlja. Besides a short description of the Codex 41, in the introductory study I give some basic information with regard to the text and a short overview of its theological content.
\end{abstract}

Key words: Codex 41, Gregory Palamas, Gregory Akindynos, Serboslavonic translation, divine essence and energies. 